Illinois State University

ISU ReD: Research and eData

Theses and Dissertations

5-13-2021

\title{
Communism and Finance: The Lacanian Non-All and a Critique of Modern Monetary Theory
}

Michael Brian McCarthy

Illinois State University, mbmccarthy28@gmail.com

Follow this and additional works at: https://ir.library.illinoisstate.edu/etd

\section{Recommended Citation}

McCarthy, Michael Brian, "Communism and Finance: The Lacanian Non-All and a Critique of Modern Monetary Theory" (2021). Theses and Dissertations. 1453.

https://ir.library.illinoisstate.edu/etd/1453

This Thesis is brought to you for free and open access by ISU ReD: Research and eData. It has been accepted for inclusion in Theses and Dissertations by an authorized administrator of ISU ReD: Research and eData. For more information, please contact ISUReD@ilstu.edu. 
COMMUNISM AND FINANCE: THE LACANIAN NON-ALL AND A CRITIQUE OF

MODERN MONETARY THEORY

\section{MICHAEL McCARTHY}

70 Pages

Financialization transforms capitalism from the Lacanian "All" to the "non-All". It can adapt to the infinite variations of class structures under capitalism because it subjects the very form of capitalist accumulation to risk through financial speculation. This variability and durability is potentially of interest to anti-capitalists who seek to avoid the pitfalls of twentieth century communism in the pursuit of an economy not based in exploitation. By investigating the relationship between Modern Monetary Theory and financialization under capitalism, new possibilities for an anti-essentialist and infinitely variable communist non-All begin to emerge. KEYWORDS: Lacanian psychoanalysis, Marxism, financialization, Modern Monetary Theory, antagonism, hegemony 
MODERN MONETARY THEORY

MICHAEL McCARTHY

A Thesis Submitted in Partial Fulfillment of the Requirements for the Degree of

\section{MASTER OF SCIENCE}

Department of Politics and Government

ILLINOIS STATE UNIVERSITY 
Copyright 2021 Michael McCarthy 
COMMUNISM AND FINANCE: THE LACANIAN NON-ALL AND A CRITIQUE OF

MODERN MONETARY THEORY

MICHAEL McCARTHY

COMMITTEE MEMBERS:

Kam Shapiro, Chair

Intan Suwandi

Julie Webber 


\section{CONTENTS}

Page

CHAPTER I: INTRODUCTION 1

CHAPTER II: POLITICS AND THE POLITICAL IN MODERN MONETARY THEORY 11

$\begin{array}{ll}\text { The MMT State } & 16\end{array}$

How Economic Concepts Shape the Political in MMT 21

CHAPTER III: MMT FROM FINANCIALIZATION TO COMMUNIST NON-ALL 33

MMT, Neoliberalism, Imperialism, and Financialization 36

Financialization and the Incorporation of Antagonism 55

From MMT to the communist non-All 64

$\begin{array}{lc}\text { REFERENCES } & 68\end{array}$ 


\section{CHAPTER I: INTRODUCTION}

Whatever the working class is, it is always changing, always resistant to being fixed in place or pinned down to a singular notion. Özselçuk and Madra write that "the very notion of class itself emerges as a consequence of Marx's repeated attempts to make sense of the changing forms of economic organizations" unfolding as the feudal mode of production receded and the capitalist mode began to predominate (Özselçuk and Madra 2005, p. 84). In this view, the working class is multiple and always shifting because it is constructed on uneven ground. Indeed, there is something perpetually transitory about capitalism itself: it is always in the process of being made. New capitalist class structures often emerge from non-capitalist forms of production. Yet Özselçuk and Madra find that capitalism is beholden to a limit. They use the Lacanian notion of the "all" to describe this limit as a response to a fundamentally antagonistic social field that must delimit an acceptable range in which antagonisms can occur. For capitalism, they write, this limit is that "the reproduction of the exploitative form of appropriation is not jeopardized" (Özselçuk and Madra 2005, p. 88). However, I argue that today financialization does away with this limit and yet capitalism remains intact. Today, financialization does not rely upon any fixed notion of class but is able to incorporate the infinite variability of class into the calculations necessary to maintain the accumulation process. The quantifications of the risk of class struggle can be packaged into securities like derivatives and traded as capital. Financial assets allow for new ways of managing capitalism that do not impose limits but instead commodify ineradicable antagonisms and make them work for an accumulation process. In Lacanian terms, this means that financialization has done away with the capitalist-all and instituted the capitalist non-All [pas tout]. This transformation lends a new durability to capitalist relations of production by accepting the antagonisms that threaten those 
relations as ineradicable. The capitalist non-All gives antagonism a proper place within the capitalist relations of production. This transformation in capitalism suggests the possibility of a similar transformation in communist politics that I seek to theorize here.

Twentieth century communism was a politics of the communist-all. Zupančič writes that "Abolition of the non-relation has been in fact the way in which the authentic revolutionary projects of the twentieth century often understood the path to radical emancipation" (Zupančič, p. 30-31). The all attempts to abolish the non-relation that generates the antagonistic social field and the non-All makes the non-relation integral to building "a narrative of a higher Relation" (Zupančič, p. 31). Financialized capitalism is building this narrative of a higher Relation even as it incorporates antagonisms into the process of capitalist accumulation. Today, we often hear of the "democratization of finance," the liberatory potential of "passive income," and the compatibility of financialized capitalism with a robust welfare state. This last narrative is expressed in Modern Monetary Theory (MMT). MMT is one of many possible narratives of a higher Relation compatible with financialization that appropriates the non-relation between classes for the furtherance of capitalist accumulation through exploitation, but one that may be especially useful for a contemporary communist movement that seeks to build a communist nonAll. Although MMT is increasingly popular on the Western Left, its orientation toward antagonism reveals it to be compatible with financialization that allows capitalist power to proliferate. As the following chapters will show, for MMT, money itself becomes a rational and technical (or rational-technical) means by which to moderate struggles, thereby blinding itself to the fundamental antagonisms that shape the social field of financialized capitalism. I pursue an understanding of the potential for a communist non-All through a reading of MMT as a capitalist 
theory of political economy that responds to the conditions of financialization without ever challenging them at a foundational level.

To set the stage for this reading of MMT, it is helpful to turn to an analysis of class antagonisms in capitalist political economy. The historical development of capitalism out of other forms of production is ongoing. Özselçuk and Madra’s claim that class as a notion develops out of Marx's historical analysis of the transition from feudalism suggests that history is a process of the transformations of class structures. This makes it impossible to speak of capitalism without a theory of the perpetual transition to capitalism. Capitalism (and indeed, any form of social organization) is never complete. As a result of this incomplete social organization, the working class is multiple, global, and can be made to serve the expansion of capital even in non-capitalist economies. On this last point, Bhattacharya and Seda-Irizarry argue "any account of capitalism that does not recognize non-capitalist class structures obscures the continuous and central role of primitive accumulation to the valorization of capital" (Bhattacharya and SedaIrizarry, p. 331). Non-capitalist economies provide capitalists with continuous opportunities to impose various new forms of economic organization to accumulate capital by dispossession, thereby shifting the composition of the working class in those economies but never settling on some "normal" relation between classes. The functioning of capitalism relies upon the multiplicity of class structures, the ever-changing actuality of class as a form of economic organization, and the plasticity of the working class. At the same time, "the Worker does not exist" (Zupančič, p. 33). Indeed, the worker as "subject" is always alienated from the "substance" of work through the paradoxical valuation of labor under capitalism that Zupančič describes thusly:

Labor is a product among other products, yet it is not exactly like other products: where other products have a use value (and hence a substance of value), this particular 
commodity "leaps over" or "lapses" to the source of value. The use value of this commodity is to be the source of value of (other) commodities. It has no "substance" of its own (Zupančič, p. 33).

Under this conception, the worker is left to sell their labor as a commodity even though labor is the source of value of commodities. The worker sells their labor as if they were a capitalist selling a commodity, and yet the lack of a direct use-value makes labor into a strange commodity indeed. I argue that it is precisely this negation of the singular form of "Worker" that actualizes the multiple contingent organizations of the "working class." Each contingent economic organization of the working class is a reaction to the impossibility of the emergence of the Worker. The working class is multiple because of its negativity. Financialization itself has made use of this negativity and done away with "the naive belief in the possibility of a nonantagonistic and harmonious way of organizing and regulating the processes of production, appropriation, and distribution of surplus" (Özselçuk and Madra 2005, p. 85). Since there is no "normal" form of organizing and regulating capital that is free from antagonism, this means that class struggle is an inherent risk to capitalism. There can be no capitalism without class struggle and class struggle threatens to bring capitalism to the point of crisis. Capitalism therefore requires various strategies and technologies for the management of crisis. It is my goal to study financialization as a mode of managing capitalism that incorporates non-relation into the process of accumulation. From that study, I develop an outline of how a political movement for the communist non-All can take shape by incorporating the antagonisms that undermined twentieth century communism.

Financialization today provides capitalism with a new way to manage crises. Though it has often been theorized as contrary to the process of production and accumulation, "Financialization is not the result of some fatal and persistent inability of capitalism to restore 
profitability or to realize surplus value" but rather is a particular technology of capitalist political economic power (Sotiropoulos and Lapatsioras, p. 99). The failures that are often associated with financialized capitalism are in some sense constitutive of capitalism's durability and its success. Financialization accepts the inevitability of antagonistic class struggle in capitalism and so does not move to repress antagonisms. Indeed, financialization accepts that for capitalist accumulation to continue, every assumption of capitalist political economy must be made fluid and negotiable. Even the form of accumulation itself is put up for wager. Other technologies of power can directly repress the working class, but financialization "provides a representation and quantifications of different power and social relations in general" that can be used in the management of capitalist political economic power (Sotiropoulos and Lapatsioras, p. 92). That is, financialization can conceive of class struggle in monetary terms and thus transform class struggle itself into another commodity. Once every aspect of capitalist accumulation is reconciled to risk, the commodification of risk makes capitalism more durable.

In Lacanian terms, financialization transforms capitalism from the capitalist-all that Özselçuk and Madra consider limited by the form of accumulation through exploitation. The capitalist non-All of financialization, however, has no such limit because it accepts that even the form of accumulation through exploitation is at risk. However, class struggle can be commodified, its risks assessed in monetary terms, and even the sacrifice of accumulation by exploitation can be made potentially profitable. The commodification of class struggle leaves nothing off the table and puts every aspect of capitalism itself up for exchange in financial markets. Zupančič describes the non-All as a type of magnetic charge within a discursive field:

So: the something produced by the signifier, in addition to what it produces as its field, magnetizes this field in a certain way. It is responsible for the fact that the symbolic field, or the field of the Other, is never neutral (or structured by pure differentality), but 
conflictual, asymmetrical, "not-all," [non-All] ridden with a fundamental antagonism (Zupančič, p. 41).

This magnetism is the driving force behind the durability of financial capitalism. Even though everything is put up for wager in financialization and there are no strict limits to the form of capitalist economic organization, the exploitative form appears again and again. Zupančič’s magnetism here accords with Marx's notion of "tendential laws" because there are no strict limits on the form of economic organization and yet economic organization tends to take certain forms. Financialization creates a symbolic field that is charged toward accumulation while nonetheless accepting the ineradicable antagonism between the bourgeoisie and various contingent formations of the working class that put that accumulation at risk. Rather than an all that imposes a strict limit on the form of economic organization, financialization is non-All because it accepts conflict and antagonism as inevitable and fundamental parts of social organization. To understand financialization in Lacanian terms is to understand how putting accumulation through exploitation up for wager makes capitalism a more resilient and totalizing form of social organization. The risk of a revolutionary subject overthrowing the capitalist system is incorporated into the functioning of capitalism itself. Allowing for this antagonism permits the social field its magnetic charge. The possibility of revolutionary class struggle magnetizes the social field of financialized capitalism. So long as capitalism is based in the paradox of the value of labor and the working class is generated by the paradoxical status of labor in the valuation of commodities, "all attempts at 'fixing' class are bound to fail" (Özselçuk and Madra 2005, p. 87). If all attempts are bound to fail, then what of the non-all? It is precisely by refusing to fix classes in place that the capitalist non-All of financialization is so able to maintain the capitalist system. 
Financialization benefits from a certain conceptual slipperiness. As a term, it is difficult to pin down. Theoretical texts on the topic often begin with a disclaimer such as, "There is no generally agreed definition, or even understanding, of financialization" (Lapavitsas 2011, p. 611; see also Sotiropoulos and Lapatsioras, p. 89). In these respects, Zupančič’s discussion of an entirely different subject, sex, is apropos. She writes, "The paradoxical status of sex is the opposite of, say, the status of unicorns" (Zupančič, p. 22). We know that unicorns are not real but can very accurately describe the idea of one, while we know that sex is real but lack the ability to formally define the idea of sex. The same is true of financialization: we know it is real but lack the ability to formally define the idea of it. This lack of a formal definition makes for an economic arrangement that is infinitely variable instead of beholden to a singular limit. It is the conceptual slipperiness of financialization that grants capital its adaptability to the multitude of class structures.

There is something of value for anti-capitalists in the capitalist non-All. The twentieth century communist projects were marked by a fantastical vision of the communist-All. In this vision, the communists would anticipate dialectical progression and bring about the final resolution of the antagonism between classes through violence. The politics of the all are a social-ideological fantasy and "the stake of social-ideological fantasy is to construct a vision of society which does exist, a society which is not split by an antagonistic division, a society in which the relation between its parts is organic, complementary" (Žižek 1989, p. 142). Twentieth century communist attempts to realize the Worker as a real subject failed to fix a single set of class relations in place as the normal or post-political relations. There was no harmony between the classes in the twentieth century communist projects. Ultimately, the political violence and repression meant to maintain the project of the communist-All were incapable of doing so. 
Financialization, however, suggests that perhaps there is a method for communists to incorporate antagonism itself into their politics and to create an asymmetrical and antagonistic communism that does away with exploitation but that recognizes that fixing any single subject as the definitional case for the Worker or as the recipient of the social surplus is impossible.

However, the ontology of money is more complicated than the chartalist perspective put forward in MMT supposes. The name "modern" monetary theory is a tongue-in-cheek joke because MMT accepts that "Money has existed for at least 4,000 years" in a form recognizable to modern people (Mitchell et al., p. 39). MMT draws no distinction between money from 4,000 years ago and money today. The MMT account of money begins in "The history of Egypt and Babylonia" and in the practice of "wergild" among Germanic tribes (Lapavitsas and Aguila, p. 7). In this anthropological account, money gains its value from the potential for violent reprisal for debts unpaid. Force, not precious metal, backs up the value of money. The state, with its capacity for violence, carries on this tradition. However, as the following chapter shows, this view of the state allows MMT to let the capitalist class off the hook for its antagonistic relationship to the working class. In the MMT account, antagonism is optional because "capitalist systems can have 'big governments' that actively manage the economy to the benefit of the majority of the population, or they can have neoliberal governments that cater to the rich and powerful" (Mitchell et al., p. 40). This reduces antagonism to the level of "bad policy." Here, violence becomes a neutral policy tool to enforce good governance for all instead of a method of winning antagonistic struggles and suppressing one's enemies. However, in the Lacanian Marxist perspective,

"class antagonism" is not simply conflict between different classes but the very principle of the constitution of class society, antagonism as such never simply exists between conflicting parties; it is the very structuring principle of this conflict, and of the elements involved in it (Zupančič, p. 41). 
The difference between the rational-technical politics of MMT and the Marxist critique of political economy reveals the ways in which MMT cannot conceive of financialization as the discursive field in which new antagonisms are formed. The manipulation of monetary policy by the state as a rational-technical strategy cannot eliminate or subsume antagonisms. Money is itself an object that can be manipulated by financialization and transformed into a tool of antagonistic struggle against the working class. Žižek writes that money "possess[es] an opaque empirical being and not full actuality" because its value is not derived from its being a piece of paper but from its representation of the paradoxical social non-relation of labor, that is, from its failure to fully capture the notion of value within its being as a piece of paper (Žižek, p. xix). This introduces the antagonistic relationship between classes back into the analysis of money, whereas MMT supposes that money derives its value from the obligation to the state. The Marxist account meanwhile holds that "Money is a commodity that emerges spontaneously and proceeds to act as the organiser of the total social labour, when production is dominated by private, autonomous, and independent units" (Lapavitsas and Aguila, p. 8). That is, money emerges not from the state but precisely under the conditions of the domination of production by the private sector. Financialization, through derivatives, renders even the different forms of class struggle in monetary terms, incorporating those struggles into the process of accumulation (a topic for Chapter III). Money cannot play the role that MMT ascribes to it - the role of serving "the majority of the population" — so long as money is a tool of private capitalists and so long as financialization incorporates the price of class antagonism into financial assets. Money can organize the economy, but I aim to show how under capitalism, this will never be as democratic as MMT adherents believe it to be because the rational-technical politics of MMT are blind to the political antagonisms shaped by financialization. 
Yet, inasmuch as MMT, reframes the economy in social terms rather than as some inert natural entity, it can be further developed and repurposed for the movement for a communist non-All. Charting the failures and potential areas for further development within MMT provides a vision for a democratic and antagonistic politics that can challenge capitalist hegemony without resorting to the fixed notions of class that prevailed in twentieth century communism. 


\section{CHAPTER II: POLITICS AND THE POLITICAL IN MODERN MONETARY THEORY}

MMT is undergoing a turbulent adolescence, longing for an identity of its own, for meaning, for purpose. One post-Keynesian critic of MMT calls attention to this still-forming identity by writing, "There is nothing new in MMT's construction of monetary macroeconomics that warrants the distinct nomenclature of MMT" (Palley 2013, p. 2). It is not just postKeynesian macroeconomics that MMT struggles to distinguish itself from, as Ur-orthodox economists like Larry Summers or Greg Mankiw agree with many of the central points of MMT, such as the need for countercyclical fiscal policy. Yet, importantly, though its principles are still up for debate, its political importance precedes it, this theory has drawn an incredible amount attention - favorable and less-than-favorable — from economists, social scientists, politicians, and activists. Whether it is different from post-Keynesianism, whether it is economically sound, or whether it is internally coherent, it is already changing the political landscape. By the time the first MMT textbook, Mitchell et al.'s Macroeconomics, was published in February 2019, it had already been three years since leading MMT theorist Stephanie Kelton served as a senior economic advisor to Bernie Sanders's 2016 presidential campaign (a role she would resume in Sanders's 2020 campaign). Now it is commonplace for figures on the Left fringes of American electoral politics to invoke MMT by name. The Debt Collective, an offshoot of 2011's Occupy Wall Street protests, later adopted concepts from MMT in their propaganda and in the formulation of their issue-based campaigns, such as their student debt strike. The politics of MMT are already outpacing the theoretical development of the field. Rather than charting the fault lines of ongoing debates in MMT, this chapter is meant to understand how MMT has engaged with contemporary politics around issues of collective action, money, and finance. 
How can a movement form around a theory that is still so adolescent? The peculiar advance of MMT can be explained best by its new rhetoric that emphasizes the role of politics in the formation of the economy. The rhetoric of MMT has contributed new metaphors that emphasize intentional, deliberate, and collective action in the economy, displacing orthodox metaphors that liken the economy to forces beyond control. A metaphor has staying power in the mind and can be difficult to overcome. In MMT, theorists draw on studies from psychology to understand the enduring role of metaphor in abstract concepts, citing "the embodiment hypothesis" wherein human bodily "actions lead to the development of sensorimotor concepts that are extended into abstract theoretical domains through primary metaphors, which are embodied through our experience of being in the world" (Connors and Mitchell, p. 6). These metaphors communicate economic activity in terms of human sensory and motor experience, as though you could climb a staircase alongside interest rates or feel the heat radiating off the inflation rate. Until recently, heterodox thinkers struggled to describe concepts without returning to prevailing metaphors of the orthodox neoclassical economics. MMT advocates recognize that orthodox economists have mastered the "models that constrain our thinking [that] operate at a largely unconscious level" and have thus successfully determined "the way economics debates are framed in the public discourse" (Mitchell et al., p. 120). They question pervasive metaphors like "[the] household budget analogy", which asserts household budgets and government budgets are comparable, emphasizing instead "the special characteristics of the government's currency monopoly" (Connors and Mitchell, p. 9). This reframing figures the economy as a field of human action rather than an apolitical or pre-political nature. Instead of explaining the economy as something that must be allowed to grow according to natural laws, MMT rhetorically constructs the economy as the built product of deliberate social action. 
It is at this point that MMT's adolescent identity crisis becomes a concern. While it is undoubtedly beneficial to move away from the macroeconomic orthodoxy's tendency to theorize the economy as something natural and thus prior to human social activity, MMT's own political metaphor, based in tropes of popular identity and democratic consensus, ignores the role of antagonism in capitalist political economy. The result is a theory of politics that lacks a theory of the political. Mouffe makes the distinction between the two in this way:

Some theorists such as Hannah Arendt envisage the political as a space of freedom and public deliberation, while others see it as a space of power, conflict and antagonism. My understanding of 'the political clearly belongs to the second perspective. More precisely this is how I distinguish between 'the political' and 'politics': by 'the political' I mean the dimension of antagonism which I take to be constitutive of human societies, while by 'politics' I mean the set of practices and institutions through which an order is created, organizing human coexistence in the context of conflictuality provided by the political (Mouffe 2005, p. 9).

A charitable reading could place the MMT conception of the political in the vein Mouffe here associates with Arendt, though statements asserting that "The government is not a moral arbiter but a functional entity serving our needs" suggest a more technical role for the state than might be found in Arendt (Mitchell et al., p. 122). The metaphors of MMT rely on an already-existing notion of politics, that is, on a contingent form of politics. This contingent form of politics, elevated to the universal in MMT, obscures the importance of the political in the formation of any contingent form of politics. For Mouffe, "every society is the product of a series of practices attempting to establish order in a context of contingency" (Mouffe 2005, p. 17). For MMT, with its basis in politics, rather than the political, this means that this contingency obscured as politics is elevated to the level of the universal. The metaphors of MMT suggest that politics as it is experienced today encapsulates the whole realm of the political. The sensorimotor experience of politics obscures the potentiality of the political. Mouffe writes that this is true of the social generally, that "The social is the realm of sedimented practices, that is, practices that conceal the 
originary acts of their contingent political institution and which are taken for granted, as if they were self-grounded" (Mouffe 2005, p. 17). Because MMT puts politics before the political, it fails to conceive of the political as antagonistic and politics as contingent. In this conception of the political, small scale collective accomplishments are compared with the power of the state. However, Marxists and post-Marxists like Mouffe would challenge this rational perspective on the state because of the antagonisms it conceals. For them, the state is not a teambuilding exercise, nor a unit formed with a singular goal. The small-scale experience of collective accomplishment ignores the antagonistic foundation of the political in favor of a cooperative experience of politics. While antagonism may not be the result of a natural law, it is still a necessary component of capitalist political economy, as I intend to show. In their rhetorical construction of politics, MMT theorists conveniently ignore the role that contestation and violence play in the political composition of the economic.

My aim in this chapter is not to bury MMT, but rather to revise its central political metaphor to make explicit the role that antagonisms play in capitalist political economy. Once this is accomplished, it will become clear that the rhetorical politics of MMT currently serves primarily to build a better form of financialization within capitalism rather than challenging capitalism itself. By showing how MMT bolsters financialization that incorporates antagonism into the project of accumulation itself, I hope to demonstrate the contingency of the MMT concept of politics and the antagonisms this concept relies upon at the level of the political. MMT has made a major step in the right direction by recognizing the political construction of the economy, flawed as its conception of the political may be. Its rhetorical displacement of the nature metaphors of orthodox economics is to be commended. However, its central metaphor provides a rosy view of the political that should be challenged. As Mouffe argues 
"acknowledging the ineradicability of the conflictual dimension of social life, far from undermining the democratic project, is the necessary condition for grasping the challenge to which democratic politics is confronted" (Mouffe 2005, p. 4). To democratically confront the construction of political economy requires introducing an antagonistic conception of the political and so we must challenge the central metaphor of MMT. The economy is the product of political activity, but political activity is necessarily antagonistic. Therefore, the economy is itself shaped by antagonism. If MMT reconfigures its central metaphor around the political and the constitutive antagonisms underlying any politics, then this metaphor can be used to challenge both financialization and capitalism writ large. I hope to show how this theoretical adjustment to the central metaphor of MMT returns the political to politics. This reversal of the MMT formulation of the relationship between politics and the political puts the political first. From this, other domains, such as the economy, are contested politically but agonistically instead of antagonistically. I hope to show how the demand for an agonistically contested economy can give rise to a movement for a communist non-All. An agonistic movement would incorporate antagonisms, though not for the accumulation of profits, but for the democratic distribution of surplus. A counter-hegemonic bloc of workers, women, racialized people, indigenous people, environmentalists, the disabled, queer and trans people, and colonized people could incorporate the agonistic politics into the distribution of surplus democratically just as MMT advocates theorize how financialization can incorporate economic antagonisms for the benefit of some sovereign "we" or "people" that remains vaguely defined.

To make this argument, I will first delve into the rhetorical reframing of the relationship between the state, the people, and money to draw a theory of politics out of MMT. Then, I take up the MMT notion of "pyramiding currency," which describes the diffusion of money from the 
government through financial institutions and finally into the hands of households and develop a companion theory of "pyramiding sovereignty" to describe the similar dynamics by which the MMT state distributes political power. Third, I address the relationship between financialization and the MMT state, especially focusing on the MMT analysis of the Great Financial Crisis to show how its critical position toward financial institutions is limited to a rational-technical need for reform. Fourth, I theorize how MMT can furnish the theoretical tools needed to break free of the narrow limits of the MMT state in a more authentically anti-capitalist project of democratic distribution of surpluses.

\section{The MMT State}

As an economic theory MMT begins with the belief that "fiat currency is valued and widely used in transactions because it is required as the means to pay taxes and other obligations levied by the state" (Mitchell et al., p. 134). This belief, called either chartalism or neochartalism, makes the state the first actor in matters of modern economic policy, from which all further actions stem. Neo-chartalism distinguishes MMT from orthodox macroeconomics because the latter supposes that markets provide money with its role as a unit of account, store of value, and means of exchange even though the treasury prints the physical bills. Such a view places the state as one actor among many in the market, an actor whose actions are constrained by market logics in the same way that households and firms are constrained.

To distinguish the political content of MMT from previous chartalist theories of money, it is helpful to turn to a Marxist critique of both the orthodox and chartalist perspectives and then to evaluate what precisely makes MMT different. One Marxist critic writes of an antecedent chartalist theory, "the rationale for the institution of money is not really situated within actual agent-agent relations (respectively exchange relations and debt relations), but unfolds from the 
undisputed agency of a single metaphysical entity (respectively the market and the state)" (Sgambati, p. 13). To understand "actual agent-agent relations" in this view requires dismantling monolithic visions of the state and government. However, the state in MMT poses some challenges in this regard because, in the framing of MMT, "We create government as our agent to do things that we cannot easily do ourselves" and "In this narrative, people create the economy" (Connors and Mitchell, p. 4). Such a view requires the state be a monolith. By positing that states have potentials that people do not have, the state must in some way transcend the people who found it. In order to structure the economy, the MMT state must become a monolith unlike the actual agent-agent relations that formed it. This theory runs into some problems right away. For one, a monolithic theory of the state can only conceive of economic inefficiency as the result of a single actor. Thus, politics becomes an optimization problem undertaken by an undifferentiated actor working in the interest of the entire polity. A monolithic theory of the state cannot account for antagonism between agents because it is the sole agent of political action and it represents all sides of every antagonism it contains. In an optimization problem, antagonism is merely a tricky problem to be managed away. In MMT, democracy itself plays the role of management technology, with majorities serving primarily as a check on corruption. Underexplored, however, is the role that coercive power plays in the foundation of any state. Why is it, after all, that government can do so much more than we can do ourselves? By what means does the monolithic state gain new potentials not held by the people who created it? Coercive force sets the state apart from the people. MMT skirts over the foundational role that violence plays in the state's ability to shape the economy. By highlighting coercive force it becomes clear that antagonisms can produce efficiencies as well as inefficiencies, state violence can be productive and make the economy grow, the economy is not merely a problem of 
optimizing regulatory technologies, and that the creation of money by the state is linked to the state's potential to use coercive force. A key example to illustrate this point comes from the Macroeconomics textbook, which offers a brief economic history of slavery. It states that slave societies were "weak" and "unstable" because "slave society... is operated for the benefit of the slave owners (that are relatively few in number), and...the (typically) larger number of slaves recognise that their lives would improve through revolution and emancipation" (Mitchell et al, p. 41-42). The antagonisms between slave owners and slaves are resolved by the slaves recognizing a higher form of economic efficiency and making a popular revolution to reach that form. In this scenario, democracy is merely more technically efficient way to produce and distribute resources. Mitchell et al. root the weakness of slave systems in the antagonistic relationship between slave owners and slaves but fail to theorize the reason why those antagonisms would emerge in the first place. This scenario, taken to its extremes, renders the unsettling conclusion that perhaps slavery was desirable because it marked an increase in overall efficiency precisely because it immiserated the slaves. If that is the case, one shudders to think what other brutal utilitarian calculations MMT can lead to. Revealingly, Mitchell et al. write that "Even in the most enlightened form of slave society, force is required to preserve slavery" (Mitchell et al. p 41). Of course this is true, but the point is not made for other forms of state society, like capitalism. Even in the most enlightened form of MMT capitalism, is force required? If we are to believe that the state is necessary for the creation of neo-chartalist money alongside the view that the state is distinguished from the people precisely by its violence, then the answer must be yes.

Thus, when viewed together the MMT state and MMT's neo-chartalist conception of monetary creation appear to work in tandem. Like the orthodox theory of market logic, the MMT state is theorized as efficiency-seeking through its structure. The moment that the people 
recognize the potential for the organization of coercive force is the inaugural moment of the state. The view of the state as a "single metaphysical entity," rather than an assemblage of people, in turn leads to a peculiar theory of how money is created (Sgambati, p. 13). Sgambati writes that — contra MMT and orthodox economics — studies of money and finance ought to pay more attention to "the actual conflicts and negotiations occurring among proprietors - and especially among those who make money - and how these relations contribute to the shaping of modern forms of sovereignty and property" (Sgambati, p. 29). Where Connors and Mitchell view sovereignty as a prerequisite for the formation of money, Sgambati views the state and market as the results of ongoing antagonistic struggles. Sgambati characterizes the relationship between the state and neo-chartalist money as "the ad hoc agency of the state as a violent foundation for money" (Sgambati, p. 14). The neo-chartalist theory of money at the heart of MMT relies upon the belief that the requirement to pay taxes establishes the demand for money, that is, that taxes make markets. This is contrary to the orthodox view in which the market takes on a monolithic role in the creation of money through the demand for a currency.

However, the neo-chartalist belief that taxes drive markets is further developed in MMT. The problem is that in the neo-chartalist theory of the state as the biggest debtor, the theory "assumes the existence of a saturation point in the government's capacity to deficit spend (hence of a limit to its power to impose a tax) that is ultimately determined by market-driven considerations of supply and demand", which shows that "Ineluctably, the moment the state starts 'making the market', the market also starts 'making the state'"' (Sgambati, p.16). Not only is the MMT state thus not inherently democratic, but it also undertheorizes the potential for market forces to shape state objectives. Not only is MMT not inherently tied to democracy, this tendency for markets to make the state is evidence that the MMT state is inherently anti- 
democratic, subject to the wiles of anti-democratic market forces. State violence would thus remain within the command of the rich and directed upon the working class even after the successful implementation of an MMT fiscal policy.

The drive for an efficient MMT state is thus disciplinary, though it retains a weak tie to certain forms of democratic participation, the extent to which state power is determined by the markets remains undertheorized. This undertheorization is perhaps nowhere more evident than in the lack of a theory of inflation. Palley writes, "though full of boilerplate disclaimers about the need to take account of inflation...MMT lacks an explicit theory of inflation, how inflation impacts the economy, and how that impact complicates policy" (Palley 2013, p. 14). This is to say that MMT economists understand that there is a limit — what Sgambati above refers to as a "saturation point" - to the amount of deficit spending that can be undertaken by the state, though it lacks a theory of what that limit might be. This limit determines the extent to which the state is subject to the market. Beyond its negative economic impacts, inflation is thus a limit on the power of the state. Even in non-inflationary economies, the shadow of inflation compels state action. A theory of economic democracy should thus not content itself to say that inflation is a far away shadow, incapable of intervening in the affairs of an economy built by deliberate human action, as Kelton does when she decries the "deficit bogeyman" (Kelton, p. 1). By sussing out what MMT leaves undertheorized, I hope to demonstrate not only that the MMT state fosters and benefits from antagonisms between classes, but how it does so. Inflation is perhaps the most readily apparent case in which this is true because the inflationary limit on the state's action will always operate as a constraint on state action, and if surpassed will give inordinate powers directly to the capitalist class via financial institutions with their own ability to create different 
forms of credit and thus shape markets. The neo-chartalist theory of money is therefore always contingent upon the role of financial institutions in monetary creation.

The following section draws on some of the key economic concepts in MMT to develop a theory of how the state distributes power to other economic and political agents based on the MMT concept of "pyramiding currency" and other related concepts like functional finance that present a new means of financializing ever greater portions of the economy. Such a theory will allow us to develop conclusions as to how the MMT state incorporates the antagonisms that define Mouffe's concept of 'the political' into the daily functioning of 'politics' by taking the side of the capitalist class via the financial institutions that the MMT state would further empower. Inflation, as an egregious case, is not the only way that the state surrenders power to the market. Indeed, the normal functioning of the MMT state is reliant upon leveraged assets created by financial institutions. It relies upon them precisely for the role of incorporating antagonism into the process of accumulation.

\section{How Economic Concepts Shape the Political in MMT}

Kelton writes that "If the government tries to spend too much into an economy that's already running at full speed, inflation will accelerate. There are limits...MMT distinguishes the real limits from delusional and unnecessary self-imposed constraints" (Kelton, p. 3). However, the question of how much inflation is acceptable or how to identify the limits of deficit spending, is left unanswered. For the moment, this undefined limit haunts MMT. The rhetoric of MMT does dispel the delusional and unnecessary aspects of orthodox economics that say seek to impose a financial constraint on government spending such as a balanced budget requirement, but MMT does not define the point at which the real economy is constrained by the physical limits of labor and capital. It is a rite of passage for MMT economists to denounce the orthodox 
metaphor that likens the government's budget to a household and yet they lack a metaphor for what the government's budget really does resemble. The metaphor of collective will falls short when inflation is precisely the result of government deficit spending. The metaphor would have to include the point at which the collective will includes its own negation. The result of this is that concepts like inflation are difficult to conceptualize in the sensorimotor register favored by Connors and Mitchell. Palley further notes that inflation is characterized by "the mix of sector conditions" in different areas of the economy, meaning that it is not merely determined by the full mobilization of labor and capital, but the appropriate mobilization of labor and capital to meet the needs of specific sectors of the economy (Palley 2013, p. 15). At the same time, "MMT analysis, based on an aggregate income-expenditure model, offers a false choice of unemployment versus full employment with price stability", ignoring the mix of sector conditions that determine the price of money (Palley 2013, p. 16-17). It is thus not merely an act of collective will to boost the economy to full employment, but also an act of determining which sectors will be given which resources. Neither does MMT account for "dollarization" as a response to economies where fluctuating exchange rates increase demand for a currency that is a more stable store of money than inflationary money of the kind created by an expansionary MMT state (Palley 2013, p. 19-20). Inflationary concerns thus shape political concerns within nations, such as the sectoral differences that shape incentives, and between nations, such as the dollarization that compels countries to surrender their credit sovereignty to pursue a currency that is a more stable store of value.

Still, MMT has been influential in policy discussions in the United States for several years now. Representative Alexandria Ocasio-Cortez remarked on the theory in a 2019 interview with Business Insider, stating, "We can pay for it with deficit spending" about a slate of policies 
including MMT favorites like a federal jobs guarantee (Relman). Her call for MMT to be "a larger part of our conversation" falls short of an outright endorsement of the theory, but highlights the usefulness of MMT rhetoric in popular politics by insisting that whether the theory stands on its own or not, it is nevertheless important to introduce into policy debates (Relman). It may be defeated in those debates, but the Left flank of American electoral politics insists that it should at least be allowed to play the foil. The popularity of the theory is thus important to this Left flank as a rhetorical device. Furthermore, the strategy seems to be working. Kelton's book The Deficit Myth, a popular account of MMT, debuted on The New York Times's best seller list in June 2020. Macroeconomics, written by founders of the field, the first textbook in the field and generally regarded as the definitive text in the field by other MMT theorists includes a chapter on "The Use of Framing and Language in Macroeconomics", suggesting that the rhetoric is as key to the theory as its mathematical models (Mitchell et al., p. 119). Though internecine debates continue, Macroeconomics has played an important role in popularizing MMT discussions as both a key collection of MMT concepts and a text aimed at undergraduate students rather than economists. It trains students in the use of this rhetoric and in its key concepts, underdeveloped as they can sometimes be. The rejection of orthodox economic rhetoric is the bridge between these sometimes-underdeveloped concepts and the politics of figures like Ocasio-Cortez and organizations like the Debt Collective. At the same time, politics is itself the central metaphor of MMT's rhetoric. The sensorimotor experience of collective action is necessarily limited to the already-existing forms of sedimented and contingent formations of politics and MMT thus maintains a limit here. I suggest that the rhetorical advance that MMT makes upon orthodox economics can be adapted to a Marxist critique that is sensitive to the antagonisms that constitute the political. 
What is the MMT perspective on the political as it stands? Connors and Mitchell posit a theory of the political that is more amenable to the idea of rational consensus than Mouffe's when they write,

We want government to act on our behalf to move us from State A (less desirable) to State B (closer to our purpose). It is important to note that the economy has no goals. They are our goals and we use, manage, and control the economy to achieve our goals (Connors and Mitchell, p. 16).

Thus conceived, the state is justified by its service to a unified "we." Politics is the process of pursuing the common goals of this "we" and thus requires a fuller identification with "we" than is provided by orthodox macroeconomic metaphors that personalize, naturalize, or deify the economy. By drawing attention to this "we," MMT gains a utility for politicians like Representative Ocasio Cortez who mean to build electoral movements. But who are we? This question has the potential to reintroduce antagonisms into MMT. Mouffe warns of speaking in terms of "we" because "the constitution of a specific 'we' always depends on the type of 'they" from which it is differentiated" (Mouffe 2005, p. 18-19). For Mouffe, whenever "they" are excluded from politics, fundamental antagonisms are soon to resurface. Macroeconomics responds to this view by leaving the question open. The authors write,

Further, no society comprises harmonious individuals and groups. There are always conflicting claims and goals that must be moderated. There is no single, obvious public purpose to which all members of a society wish to strive. Even if we can identify a set of goals that the majority of society would like to work toward, that set will surely change over time as hopes and dreams evolve. The public purpose is an evolving concept (Mitchell et al., p. 9).

In this statement, a democracy becomes a means to manage antagonisms: majorities can identify their goals, which can then be revised via an evolutionary and perpetually open process. This process also "moderates" conflicts similar to Mouffe's desire for a "tamed" politics, though the call for the moderation of goals differs from Mouffe's belief in the intractable oppositions upon 
which society is instituted. That is, she theorizes a political that can be moderated in its processes but not in its goals. A theory of the political, like Mouffe's, can perhaps help MMT avoid the trap of conflating its rhetoric, its politics, and its key economic concepts. The political determines the way in which politics is conducted. Mouffe writes that, for example, that "Antagonistic conflicts are less likely to emerge as long as agonistic legitimate political channels for dissenting voices exist" (Mouffe 2005, p. 21). Agonism here describes Mouffe's model of politics whereby the friend/enemy distinction inherent to creation of the political is staged within democratic politics rather than in conflict. The enemy is transformed into an adversary, though the irreconcilable differences central to the political as antagonism remain. This "taming" of politics is central to Mouffe's political project because it allows for democratic politics that are neither reducible to a single rational-technical logic nor destined to result in violent conflict. The Macroeconomics view of antagonism, calling for evolution and moderation, is not merely one attempt among many to craft a deliberative model of the political. It is itself an attempt to tame political antagonisms through moderation. It differs from Mouffe in that politics is not conducted on the sediment of past decisions made in favor of a single beneficiary in a political antagonism, but rather serves to moderate the concerns of both (or multiple) sides of every antagonism without creating new antagonisms. This move to the middle is conceived of as somehow constraining the fringes instead of excluding them from the hegemonic articulation of a new politics. Rather, I argue in this section that the unique concepts used by MMT advocates to describe the economy also function as tools for the incorporation of antagonisms into politics, not simply their resolution by deliberation. This differs from Mouffe's view, in which a lack of agonistic politics results in political antagonisms shifting domains and reemerging. Indeed, it is rather a method of making antagonisms central to the process of capitalist accumulation itself. 
The key example for understanding the role of the political in MMT is credit sovereignty, which holds "The sovereign government alone has the power to determine which money of account it will recognise for official accounts" (Mitchell et al., p. 136). Credit sovereignty allows the state to spend money into existence, but also distributes an aspect of that sovereignty to financial institutions by permitting them some limited control over the currency and households are granted even less control over the currency through their consumption and investment decisions. The concept of pyramiding currency is thus also a concept of pyramiding sovereignty. Credit sovereignty is not synonymous with state sovereignty as states can adopt a foreign currency or peg the value of their currency to another nation's currency or the price of gold. Credit sovereignty only belongs to those sovereign states who retain control over their own fiat currency and their own fiscal policy, thus excluding states like Eurozone members who use a single currency between multiple sovereign nation-states, and states that have seen fit to "dollarize" their economy. Credit sovereignty is built through the ability to tax and to deficit spend. In the Eurozone, the national governments that levy taxes lack the ability to spend money into existence like a credit sovereign state can. In dollarized economies, the exchange rate or currency is fixed to another nation-state's currency or directly uses that currency (not necessarily the US dollar, though this is a common case). By reversing the orthodox tax-then-spend formula by spending money into existence, MMT conceives of sovereignty in terms of the ability to grant access to the monetary system. While state sovereignty is more closely tied to the kinds of powers through which the state can collect taxes, credit sovereignty is the ability to create and bestow money. The ability to spend money is pivotal to the state's credit sovereignty because actors who receive money from the state form markets and exchange money. Mitchell et al. notice that the receipt of money by financial institutions empowers those same institutions to 
develop new forms of less-liquid money, such as money in savings accounts, certificates of deposit, and other vehicles. These other forms of money in turn are leveraged against other businesses and households, giving these financial institutions power over those businesses and households. Financial institutions, as creators of money, share in a power that resembles the power of the credit sovereign state. Mitchell et al. write,

We can think of a pyramid of liabilities, with different layers corresponding to the degree of separation from the central bank. Perhaps the bottom layer consists of the IOUs of households that are held by other households, by firms engaged in production, by banks, and by other financial institutions. The important point is that households usually clear accounts by using liabilities issued by those higher in the debt pyramid, typically financial institutions (Mitchell et al., p. 144).

In this view, money gains its value because it is used to pay off tax liabilities imposed by the state, a requirement the state imposes to shape markets. From this distribution of money, financial institutions gain the ability to lend out their money using various vehicles of their own invention and choice. When the state then spends money into existence by selecting financial institutions that in turn distribute money further down the pyramid to households and firms (as well as laterally to other financial institutions, and up the pyramid in the form of taxes) it also distributes leverage. Since the "liabilities at each level typically leverage the liabilities at the higher levels" ultimately resting on the sovereign currency as a unit used to pay one's tax liability, financial institutions become pivotal sources of monetary creation within MMT (Mitchell et al., p. 144). The credit sovereign state is the top of the pyramid so long as "Stateissued monetary forms are at the top because the state is the only agent that does not have to settle its obligations by delivering someone else's promises to pay" (Lapavitsas and Aguila, p. 4). Thus, the financial institutions share in the power of the credit sovereign state. Though the state sets the absolute limit because "Taxes reduce the non-government sector's purchasing power and hence its ability to command real resources, leaving real resources for the government 
to command with its spending" there is within any market a system of inequality and a system by which relatively few financial institutions define terms on which money is given to other firms and households (Mitchell et al., p. 323). Specific capitalists are delegated the command of real resources. Mouffe writes that "the same movement that brings human beings together in their common desire for the same objects is also at the origin of their antagonism" (Mouffe 2000, p. 131). The state and financial institutions are both forces that bring human beings together by making them rely upon the same system of monetary creation that distributes objects of common desire through the apportioning of real resources and the pricing of commodities. The MMT state creates antagonisms and through its pyramidal distribution of sovereignty manages those antagonisms.

There are other politics that manage antagonisms. For example, neoliberalism manages antagonisms, even distributes this management to non-state and market actors like the MMT state would. The important point is thus not that MMT is one of many forms of politics that seeks to manage antagonisms. This would be true of any form of politics, including Mouffe's adversarial politics whereby antagonism is managed through taming those antagonisms into agonisms. Rather, what makes MMT unique is that its method of management incorporates the antagonisms into the very process of capitalist accumulation through the capitalist non-All of financialization, a concept whose relation to political power I explore in-depth in the next chapter. To illustrate how MMT increases financialization of the economy, consider that "Private debt is debt, but government debt is financial wealth for the private sector" (Nersisyan and Wray, p. 15). Financialization has much to gain from MMT because the wealth the government initially creates and pumps into the private sector is financial wealth. This financialization of the economy stems from MMT's adoption of Abba Lerner's 1943 theory of "functional finance," 
which holds that governments should use fiscal policy to pursue economic outcomes that press against the constraints of the real economy rather than "sound finance" that is based in the household budget myth much maligned by MMT, which tethers fiscal spending to tax revenues (Mitchell et al. p. 335). This, too, is stalked by the specter of inflation. Recall Palley's criticism that inflation can result from improper stabilization of different sectors of the real economy.

The MMT response to this criticism is a favorite panacea, the "Jobs Guarantee" ("JG") or "Employer of Last Resort" ("ELR") policy. Mitchell et al. describe the need for a policy that can adapt to fit the needs of different sectors by writing,

What is needed instead is targeted policy that directs additional demand creation where it is most needed. This is not as hard as it might sound. Government does not need to keep tabs on every single sector of the economy to fine-tune its stimulus in order to help where it is most needed (Mitchell et al., p. 341).

The JG is the most frequent policy solution offered by MMT economists for fine tuning this stimulus to specific sectors. It is a policy that provides the option of a public sector job to all job seekers, subverting the rest of the currency pyramid and directly paying workers. It pumps financial wealth directly to the worker, though I endeavor to show that this has a negligible effect on the financialization of the economy. The JG is one of the clearest ways in which MMT seeks to maximize the productivity of the real economy through functional finance. Indeed, in theory the JG ensures the economy is always running at full employment and in a way that is fine-tuned to each specific sector of the economy without causing inflation. While Palley writes that "The central policy assertion of MMT is the non-existence of financial constraints on government spending below full employment" it is rather that MMT sees the JG as a method of maneuvering around these constraints through an infinitely malleable program that can always achieve full employment through specific targeting of different sectors of the economy (Palley 2013, p. 14). Mitchell et al. claim that it is possible to subvert financial constraints through the JG, and the 
recourse that Palley and other critics of MMT take is to define several further financial constraints inherent to labor markets. It is through the JG that the state is also able to "establish the money-value of an hour of work" (Lapavitsas and Aguila, p. 3-4). In this sense, the government itself is delegated the command of the real resource of labor alongside its potential to define what labor is valuable and what labor is not.

Palley considers the government's potential to set the money-value of an hour of work to be a potential cause of two different types of inflation. First, "raising the nominal wage floor will tend to spread inflation throughout the economy" and second, "to the extent that a [JG] delivers quasi-full employment, it will also tend to exacerbate income distribution conflict inflation which emerges at full employment” (Palley 2019, p. 24). Palley also identifies four other downsides to the JG: cost, potential displacement of private sector workers (as an alternative to the first inflationary scenario), perverse effects on other public sector employment and the potential for the JG to be used as a tool to bust labor unions (Palley 2019, p. 23). Because the JG must be perfectly adaptable to the conditions of the private labor market without potentially displacing workers from the private sector, JG work would by necessity be low-skill, fungible (and therefore always structured for short term), easily eliminated, low wage, and priced above the cost of private sector equivalents. Because "anti-worker governments might try to substitute ELR workers for public sector workers, thereby undermining public sector unions and public sector pay" it is possible that the JG would result in a political economic scenario that is positively hostile to worker organization, relying on workers that frequently shift from sector to sector and that work for less than their private sector comparators (Palley 2013, p. 31). The support of the JG in MMT is one of the many areas in which the economic theory is less 
developed than the politics. Take, for example, Mitchell et al.'s defense of the social effects they attribute to the JG,

In addition to income, employment also yields useful production and recognition for doing something worthwhile. While economists usually focus only on the economic multiplier, there are also social multipliers associated with job creation. These benefits include decreased crime and drug use; enhanced family and community cohesion; improved economic security, education, and healthcare; protection for the disadvantaged; environmental protection; improved local and state government budgets; more equal distribution of consumption, income, wealth, and power; induced investment in poor communities; and promotion of social and political stability (Mitchell et al., p. 292).

Here, the social is conceived of not as a site of political antagonism, but as a series of problems to be solved. Rather than abolish the family as a site of economic exploitation and cisheteronormative social reproduction, the JG would enhance family cohesion. Rather than abolish carceral logics around crime and drug use, the JG would ennoble would be criminals and drug addicts through minimum wage workfare. And so on and so on. MMT economists are concerned that "if welfare (including unemployment compensation) is offered as a substitute for a job, this has negative impacts on self-esteem" and that welfare "also wastes resources and generates social costs" (Mitchell et al., p. 243-244). The logic of MMT is clear: an unemployed worker who is not dominated by a boss creates costs to the social order itself. Of course, the JG is presented as a rational solution to a common problem to be solved in politics rather than a political problem that is the result of a class antagonism. MMT takes sides with the capitalist social order against subject positions that challenge it.

This is not a new story, not yet. Many antagonisms are already obscured behind rationaltechnical politics. What sets MMT apart from, say, neoliberalism, is its relationship with financialization. This chapter has examined the relationship between MMT and politics, focusing on the ways in which MMT economists have emphasized politics to the detriment of a political that is constituted by antagonisms. In the following chapter, I will show how MMT fulfills the 
promise of a capitalist non-All through functional finance, the JG, and other key policies that lead to increased financialization beyond the limits set by neoliberalism. I will show how, contrary to prior rational forms of politics that seek to manage antagonisms through targeted repressions of counter-hegemonic groups, MMT makes antagonisms into an integral piece of the system of accumulation itself by facilitating financialization. Functional finance, for example, creates new avenues for financialization by drastically increasing the amount of financial wealth in the private economy. MMT, which proposes to keep taxes low because the state can fund itself almost entirely through deficit spending, significantly reduces the ability of governments to check the financialization of the economy. Pyramiding sovereignty flows through the finance sector and carries with it the need to repress counter-hegemonic groups. Financial innovation opens social control of these antagonisms to financialized institutions that make the management of these antagonisms into an object of speculation. As the private economy fills with new financial wealth and the politics of MMT create incentives for antagonistic opposition to workers and other subject positions, new asset classes and financial vehicles will begin to emerge that turn antagonisms into the very fuel for accumulation itself. This financialized management of antagonisms and the Marxist answer to it is the focus of the following chapter. 


\section{CHAPTER III: MMT FROM FIANCIALIZATION TO COMMUNIST NON-ALL}

Economists — whether orthodox or heterodox, Marxist or MMT — agree that financialization describes something real, and yet "There is no generally agreed definition, or even understanding, of financialization” (Lapavitsas 2011, p. 611). This indeterminacy makes financialization fitting for study by Lacanian psychoanalysis, which foregrounds indeterminacy. Lacanian Marxists like Mouffe and Zupančič connect indeterminacy to contestation and antagonism. Writing about the place of sexuality in Lacanian psychoanalysis, Zupančič writes "The lack of sexual relation is real in the sense that, as lack or negativity, it is built into what is there, determining its logic and structure in an important way" (Zupančič, p. 18). I argue the something similar is at work in financialization, namely, its lack of a definition is central to the effects it has on the political economic discourse. Zupančič describes how non-relation, or the impossibility of a 'normal' relation (e.g., there is no "normal" sexual relation), is the condition of possibility for the contingent relations that compose the social field. She writes, "The nonrelation is not the opposite of the relationship, it is the inherent (il)logic (a fundamental 'antagonism') of the relationships that are possible and existing" (Zupančič, p. 24). In the case of political economy, the non-relation between classes is thus pivotal to the project of capitalism and financialization is the discursive logic through which this antagonism is expressed today. Financialization is an (il)logic of capital accumulation tasked with articulating the multitude of contingent class relations made necessary by the impossibility of normal class relations in capitalism. This is not a definition in the sense that it does not affix a singular meaning to these class relations nor any specific set of class structures. To put it another way, financialization is the distorted field in which subjectivities (as opposed to identities) themselves are formed in antagonistic relation to one another. I will argue that financialization as an (il)logic is the 
Lacanian "non-All" of capitalism today, which is an innovation upon the "capitalist-all" that Özselçuk and Madra describe but that falls short of their vision of a "communist non-all." For them, the capitalist-all means that capitalism can vary infinitely, but that its supposed infinite variation is the product of a limitation, namely, the exploitative form of appropriation, rather than the abolition of limits suggested by the non-all. They write, "'provided that' the reproduction of the exploitative form of appropriation is not jeopardized, 'the capitalist system' will be ready to negotiate the distribution of surplus to any recipient" (Özselçuk and Madra 2005, p. 88). In section two of this chapter, I discuss how financialization and MMT surpass even this limit by expropriating wealth from created through non-capitalist forms of production and by sacrificing the reproduction of exploitative appropriation in financial crises and in political struggles that speculators feel can be isolated from broader networks of exchange and production. Özselçuk and Madra's analysis, while crucial to understanding a communist non-all, too closely associates capitalism with the All and communism with the non-All, missing the potential of capitalism to avail itself of the non-All and the specifically communist failure of twentieth century communism, which they reduce to a different articulation of the capitalist-all despite calling it the communist-all. To put it another way, their assumption that contemporary financialized capital resembles political repression in twentieth century communist countries ignores contemporary forms of financialized political power that operate not by the imposition of limits but in the constant negation of them. Indeed, I argue that it is only by understanding the capitalist non-all and the communist-all that the potential for a communist non-all begins to appear on the horizon. To understand the capitalist non-all of financialization, it is helpful to study MMT with its relationship to antagonisms from within politics but without formal regard 
for the political. That is, MMT has a theory of antagonisms as outlying the scope of the state. This allows MMT, with its focus on the state, to cede the political to finance capital.

The argument that financialization structures capitalism as the non-all proceeds from an understanding of financialization in its relationship with neoliberalism, capitalism, imperialism, and MMT. In the following section, I develop a Lacanian Marxist critique of MMT to show that MMT is amenable to neoliberalism, financialization, and imperialism and unable to theorize beyond the capitalist mode of production. From there, I look to the way that financiers have adopted MMT to deepen financialization by granting new political power to financial institutions and incorporating class antagonisms into the capitalist accumulation process itself. I argue that the rhetorical advances of MMT upon mainstream economics help explain why it is that financialization incorporates these antagonisms into the cycle of accumulation itself as opposed to merely imposing new forms of management. Financialization does not merely attempt to repress class struggles against capitalism through the imposition of new modes of scientific management or class war but assesses those inevitable struggles for the risk they pose to capital by assigning monetary costs to class antagonisms that can be traded, securitized against, and hedged. Even the exploitative form is challenged, but the financial mechanisms that distribute the risk of this become the fuel for the process of financialization and further accumulation. I show mutatis mutandis how a communist movement could incorporate antagonisms rather than seeking to resolve all antagonisms as in the case of $20^{\text {th }}$ century communist movements. In the final section, I again turn to the rhetorical developments made by MMT and suggest that similar rhetorical gestures, informed by psychoanalysis and Marxism, can better address the ineradicable antagonisms inherent to the political and thereby shape a communist movement that can endure antagonistic politics. 


\section{MMT, Neoliberalism, Imperialism, and Financialization}

To understand the role that MMT could play for financialization, it helps to consider what financiers themselves think of the theory. In a New York Times article titled "Modern Monetary Theory Finds an Embrace in an Unexpected Place: Wall Street," Patricia Cohen writes that, "Money managers, chief executives and business analysts maintain that the approach offers several important and overlooked insights, and far from finding it fanciful or deranged, they are using M.M.T. to build economic forecasts and even trading strategies" (Cohen). Although MMT is often associated with the political Left because of its commitment to sweeping social spending programs Mitchell et al.'s claim that a politics built around MMT would have a popular appeal appears true in this case because these financiers have a fundamentally different relationship to capital than the marginalized people who are often made the subject of MMT and yet the theory appears to attempt to serve them both. Indeed, Cohen's article suggests that workers and capitalists can find a happy medium in MMT: the potential to build a Scandinavian style welfare state without increasing taxes. Here, the political movement that has adopted MMT rhetoric meets with the financial interests (i.e., anti-tax sentiment) that shape the theory. Warren Mosler, one of the leading figures of MMT is "a hedge-fund mogul who resides in low-tax St. Croix [who] helped bankroll some of the work at those schools [University of Missouri-Kansas City and Bard College], donating money for student scholarships and conferences" for the study of MMT (Cohen). It should not be discounted that Mosler found his way to MMT through rightwing politics rather than via the left. An article in The Nation describes how Mosler became "something like the movement's sugar daddy" after seeking a meeting with two major figures on the American Right:

Mosler finagled a meeting with Donald Rumsfeld in the steam room of the Chicago Racquet Club. Rumsfeld led him to Arthur Laffer, the right-wing economist who came up 
with the "Laffer curve" theory promoting low taxes, and Laffer, in turn, connected Mosler with his future collaborator, the economist Mark McNary (Abrahamian).

From there, Mosler found his way to Stephanie Kelton and the seedling MMT community that he helped to grow. To recap, meetings with Rumsfeld and Laffer led a hedge fund billionaire to begin collaborating with and funding the economist who worked as the foremost economic policy voice on the Sanders campaigns in 2016 and 2020.

The politics of MMT span Left and Right in the US such that financiers and socialists articulate similar views on monetary policy today. The agnosticism toward MMT that Representative Ocasio-Cortez showed in her interview with Business Insider is matched in Cohen's article by “Mohamed A. El-Erian, chief economic adviser at the financial firm Allianz, [who] wrote in an email that 'modern monetary theory has merit in stimulating debate"' (Cohen). That is, financiers agree that there is some rhetorical benefit to MMT beyond the initial appeal of its potential anti-tax content. While the rhetoric of MMT drives a political movement on the Left, on the Right, anti-tax politics inspire the further development of the macroeconomic theory. Thus, the underdevelopment of the theory contributes both to the development of an increasingly appealing Left rhetorical politics that the pro-financialization arm of the capitalist Right view as congruent with their anti-tax politics and their drive for greater economic insight for use in financial speculation. That a meeting between a billionaire and a neoconservative former US Defense Secretary shaped the economic policy rhetoric of the country's most famous socialist, even in this roundabout way, is perhaps cause to rethink MMT's place on the American Left. More important, though, is to consider what exactly the appeal of MMT is for financiers. The rhetoric associated with MMT can drive policy discussions around topics such as the JG or the Green New Deal that present financiers with new opportunities for investment, speculation, and arbitrage. Yet, MMT still lacks a theory of inflation for example and is in many other ways still 
incomplete, so the value of these discussions cannot solely be attributed to some rational development within the theory itself.

Like financialization itself, MMT is indeterminate. For one, its politics are not set in stone as either a right- or left-wing theory of macroeconomics. However, MMT and financialization are not indeterminate in the same way. MMT is concerned with politics as a technical-rational project. It is popular because of its advances in crafting political rhetoric, and indeterminant because that rhetoric and technical-rational project are not coterminous. Put another way, MMT has gained prominence in political debates because of its rhetorical advances on the mainstream but its lack of technical reasoning around issues like inflation leave this rhetoric with a missing referent whenever it invokes a rational-technical conception of politics. The rhetoric is a tool for debating politics, but if we accept MMT on its own terms, what is there to debate? There are only technical questions, not fundamental disagreements. Financialization, by contrast, is a characteristic of the field in which political antagonisms are shaped. Its indeterminacy is the indeterminacy of markets that have no tendency to equilibrate, to preserve specific structures of class, or specific production practices. By its abstraction from the field of real production, financialization allows the articulation of new hegemonies and new antagonisms without regard for real limits. That is, financialization can create new classes to exploit at a whim. Take for instance the gig-economy worker who drives for a rideshare company like Uber and Lyft or delivery services like Grubhub and DoorDash—a new figure in our political discourses, an exploited subject who owns the means of production (i.e., their car) that they rent to firms largely funded by venture capitalists that are committed to losing money in the short term so that they can monopolize in the long run. In this case, financialization creates a new relation of production, a new class of worker, and an aim for the capitalist that subverts the usual 
assumption that capitalists are profit-seeking as corporations pursue endless growth over profits. The worker's ownership of the means of production in this case are complicated by the unprofitable aspect of gig work. That is, because the work is unprofitable, the workers who own the means of production are still reliant on streams of finance capital that flow through VCs into the gig economy firms. The gig economy articulates a new hegemony between venture capitalists and what Bhattacharya and Seda-Irizarry call "knowledge/intellectual/intangible capital," breaking from prior hegemonies that privileged the ownership of physical capital to instead exploit workers who own their own cars, holding access to knowledge/intellectual/intangible capital apart from them through intellectual property laws, deep-pockets monopoly strategy, and other forms of exclusivity (Bhatacharrya and Seda-Irizarry, p. 340). The software infrastructure of these rideshare companies and their branding become the means of exploiting those who own physical capital and use it to produce transportation. This creates new antagonisms between this hegemonic bloc and the physical capital-owning workers while maintaining other antagonisms. For example, owners of physical capital become exploited, but the hegemony of private transportation remains in place. A Lacanian critique of finance as a symbolic order that is always ontologically incomplete (and therefore shifting) allows for an anti-essentialist Marxist analysis that can address this infinite variability of capitalist class structures.

By the same token, an enclosure of the field, like the totalizing rational-technical politics proposed by MMT economists, is never truly total. This is a point conceded in Macroeconomics, "Indeed, the economy is just one component of the social organisation that is necessary to establish the always evolving public purpose and to work towards its achievement" (Mitchell et al., p. 9). The efforts to "establish" a public purpose are always eventually subverted in a twostep dance by the tendency of this purpose to "evolve," ensuring that the politics of MMT are 
always something to "work towards" and not to be achieved outright. The field is never thus never totalized (never achieves social objectivity) because of this back-and-forth process of establishment and evolution. The totalization of the field, that is, the actual achievement of the "public purpose" is impossible, but nonetheless the goal of social organization is to attempt this impossible feat. The field on which the public purpose is defined (i.e., the political) is itself in constant flux without ever attaining equilibrium. Financialization today sets the rules of fluctuation within this field, defining the terms on which hegemonic articulations are made and unmade. That is, technocratic solutions to transportation problems that foreground the necessity of including stakeholders like venture capitalists in the solutions process create the conditions of future transportation problems. To return to the gig economy worker, the public purpose established in the past might be something like "everyone who wants a car should be able to afford one" but through financialization, the public purpose evolves into something different, like "no gig worker should be required to pay the full cost of maintaining the car they use for ridesharing." MMT's requirement to moderate demands of all parties makes solutions like wellfunded public transit less likely because there is no way for financiers to monetize it. That is, public transit will be easier won by agonistic or antagonistic insistence rather than by attempting to moderate the demand for safe, affordable transit.

The "public purpose" of MMT is constructed relative only to the internal social objectivity of the present contingent hegemonic articulation but not to the external structural undecidability of financialization that results in the evolution of what that public purpose might be. That is, the public purpose is a creature of politics that cannot anticipate shifts in the political that fundamentally rearrange the field of politics. MMT has its foot on the gas pedal but financialization holds the steering wheel. Complicating this, Laclau and Mouffe write that 
"structural undecidability is the very condition of hegemony. If social objectivity, through its internal laws, determined whatever structural arrangement exists...there would be no room for contingent hegemonic rearticulations - nor, indeed, for politics as an autonomous activity" (Laclau and Mouffe, p. xii). They state that "the category of hegemony" developed to describe the challenge that the historical development of Russian social democracy under the conditions "combined and uneven development" posed to economistic notions of historical progress, suggesting that hegemony made it possible to conceive of "historical actors" whose subjectivity was not solely determined by their status as "class actors" (Laclau and Mouffe, p. xii). Both the hegemonic rearticulation toward knowledge/intellectual/intangible capital and the potential rearticulation toward communism would be foreclosed by a purely objective social field. Following this line of thought, there is no possible objective formation of the social, only necessarily contingent and antagonistic hegemonies. There is no singular subject of capitalist exploitation opposing the capitalist class, only different partial manifestations of the negation of that class. No public purpose can harmonize classes in a normal relation of binary opposition and MMT cannot objectify the whole field of social life. Mitchell et al. allude to the problem of this antagonism by asserting, "no society comprises harmonious individuals and groups. There are always conflicting claims and goals that must be moderated" (Mitchell et al., p. 9). Here, a shifting terrain is anticipated by the rational-technical politics of MMT without being fully theorized. Why can there be no harmonious individuals and groups, after all? It is a mistake to sweep antagonisms under the rug when fully cognizant that they will inevitably resurface. Moderation of a capitalist class and a proletariat that is only the partial manifestations of the negation of that class cannot be moderated as if they were binary opposites because the proletariat's exploitation is the condition of possibility for the bourgeois class. The fundamental 
antagonism between classes means that moderation is a farce that must preserve exploitation and accumulation. Antagonisms in MMT are dealt with through determinations of what "must be moderated" to maintain exploitation and accumulation. What claims and goals does MMT seek to moderate? The capitalists would be moderated insofar as they are taxed as part of the broader effort to create money as an obligation to repay the state, and the workers are moderated in that they are unable to pursue their interests as a class, remaining subject to the hegemony of bourgeois production. Under this scheme, capitalists are free to pursue new methods of expropriation and exploitation because they accept the legitimate power of the state to compel actors into the obligation to pay tax (which ties money to that obligation) and the power of the state to spend money in the name of the people (which allows money to circulate). This bargain works in favor of capitalists because the moderation of capitalist and worker subsumes both into liberal subjects for whom democratic participation is merely a way in which rational selfinterests are tallied and weighed against one another to more closely moderate politics away from the fringes and toward the "public purpose." The notion of a shared public purpose allows liberal subjects to vote on how money should be spent into existence while the reality of financialized capital means that financial institutions capture the value created in this process. Antagonisms over the distribution of the surplus, however, remain. The financialization of capitalism means that finance is the mechanism by which this surplus is distributed, which in turn means that the rational-technical and moderating politics of MMT take place within a field that is determined by financialized capitalism.

MMT is not entirely blind to this phenomenon. The shifting terrain of the political undermines the established public purposes, but also allows the formulation of new public purposes through the identification of political antagonisms to be moderated. Concepts like 
functional finance and pyramiding currency give MMT an account of financialization that links the indeterminant politics of MMT to the indeterminant politics of financialization in a peculiar way. Both functional finance and pyramiding currency suggest that the role of the public money is to establish strong private powers, incentivizing financial institutions and providing social services and stimulus for workers. Capitalists are given new flows of financial capital to speculate with and workers are afforded the ability to pay off debts, to incur new debts, and to further entrench themselves within the financialized consumer economy. This moderates the effects of old antagonisms, though it generates new antagonisms, such as the "financial expropriation" discussed below. This is the general formula of moderation in MMT: both workers and finance are accounted for. Studies of contemporary financialization that emphasize its historical roots within neoliberal austerity often neglect the capacity of financialization to break free of the politics of neoliberalism or transform them from within. Such would be the case in MMT. The so-called "deregulation" of finance is often attributed to the neoliberal project meant to foster competition and increased profit, but "deregulation might be seen as having less to do with increasing competition within the financial sector and more to do with facilitating [interest bearing capital's] access to activity from which it was previously excluded"' (Fine, p. 58). That is, contemporary financialization has its origin in neoliberalism but is not limited to the project of austerity nor even profits per se. Monopoly strategies, for example, often explicitly eschew profits in favor of growth. MMT, like neoliberalism, lets interest bearing capital loose into new stomping grounds created by policies like the JG and functional finance that are opposed to neoliberal austerity and profitability. Financialization thus distorts the neoliberal project. Rather than pursuing the project of "deregulation," MMT instead attempts to optimize the real economy through selective regulation largely enacted through an expansionary fiscal 
policy that creates money by spending it in ways the state deems efficient. This rational-technical politics has a peculiar way of facilitating "the capitalist logic of integrating the surplus into the functioning of the system" of accumulation (Žižek 2004, p. 403). Unlike neoliberalism, MMT does not rely on austerity policies meant to allow markets to naturally correct themselves. Indeed, MMT sees inefficiencies as the intentional result of policy and derides any characterization of the economy as natural. However, MMT can work in tandem with neoliberal politics, crafting innovative new forms of austerity through stimulus. For example, Palley cautions the JG can be used to undercut other forms of public sector employment, including unionized employment. He characterizes a 2010 "employer of last resort" (JG) policy floated by the Conservative Party in the UK as "make-work activity...likely to be used by neoliberal politicians to attack government in general" (Palley 2013, p. 32). MMT is not necessarily a vehicle for the abolition of austerity as such but can follow in this neoliberal vein of rationality and efficiency maximization as highest goods. A focus on efficiency rather than antagonism produces results like this undermining of government or other forms where supposed stimulus becomes the very means by which new forms of austerity are enacted. Both MMT and neoliberalism neglect the political, thereby enabling financial capital to operate unimpeded. Palley's post-Keynesian critique of MMT is still limited because it suggests that there is still some fundamental "public purpose," and that the JG is merely not in line with it. His notion of "government in general" still presupposes an objective social field. However, by returning to a theory of the political, it becomes clear that finance capital is not tethered to an agonistic notion of public purpose and is rather the (il)logic by which class antagonisms are created and played out. Constructing the public purpose along these lines - that is, without attention to the foundational antagonism between these classes - means that moderation will necessarily not lead 
to the agonistic politics Mouffe describes but rather to a politics that is tilted in favor of hegemonic finance. Thus, Palley's critique of the JG is ultimately a rational-technical solution that does not empower democratic contestation through an agonistic transformation of politics but presumes a static political field on which politics can be conducted when this field is in truth determined by the conditions of financialization.

The politics of MMT are thus oriented around the distribution of the surplus under the conditions of financialization: where should it be allocated? Or more accurately, to whom? To answer this question, we must first ask what does it mean for surplus to be integrated into the functioning of the system? The name surplus suggests that it ought to be somehow in excess and thus incapable of integration. This failure to integrate surplus into the productive economy is one of the main drivers of financialization that Magdoff and Sweezy note. They write,

Since capitalists use their profits in order to make more profits, they will invest only if at the end of the investment process they can sell the final goods. Unable to sell all the goods produced (or, as Marx would put it, to realize all of the surplus value), capitalists slow down or reduce their investment. Profits are hoarded or used for speculation. When this happens, demand is insufficient to buy back the potential output of both consumer and producer goods, and the economy turns down (Magdoff and Sweezy, p. 52-53).

Lapavitsas and Aguila follow in the same line of thought as Magdoff and Sweezy when they write, "The state can protect and support accumulation by boosting aggregate demand but cannot direct accumulation without radical supply reforms that also involve international action" (Lapavitsas and Aguila, p. 15-16). This support for accumulation and boosting of demand is a project for MMT. The "radical supply reforms" would mean fundamentally altering the global commodity chains involved in globalized production in ways that mere alterations to domestic aggregate demand are incapable of addressing. 
In Connors and Mitchell's account of MMT, economic policy should be in service of "advancing public wellbeing and maximising the potential for all citizens with the limits of environmental sustainability" (Connors and Mitchell, p. 4). However, the three subjects Connors and Mitchell name "the public," "all citizens," and "environment" are treated as potentially demanding consumers rather than as points for the reabsorption of surplus. The state does not create surplus value except in the case of state-owned enterprises. Rather, the MMT state is capable only of supporting accumulation and boosting demand through manipulation of the money supply. Massive public spending campaigns do not challenge capitalist exploitation as such and thus even this form of stimulus effectively is merely an alteration in the money supply as workers are subjected to new forms of exploitation created by financialization, as in the financial expropriation discussed below. It is not that MMT reconceptualizes the public, citizens, and environment as rightful recipients of surplus, but rather that it instrumentalizes them in the capitalist process, extracting their "wellbeing" for a healthier and happier workforce. Wellbeing, potential, and sustainability all in turn are thus in service of the process of accumulation rather than the recipients of accumulated surplus. MMT does not use the state to direct accumulation, it uses it to fuel accumulation. Magdoff and Sweezy's point that it is part of the logic of monopoly capitalism to horde profits or seek speculative investments more closely describes how the surplus is reintroduced into the productive economy: more and more financial capital is used to speculate on smaller and smaller changes in the use of productive capital. Even though money originates in the state, it is also tethered to production and exchange. Surplus is the excess of exchange value over the cost of production. As Bhattacharya and Seda-Irizarry argue, the basis of surplus is not eliminated but rather obscured by financialization. They write, "fetishization of financial capital renders invisible living labor as the source of surplus value" (Bhattacharya and 
Seda-Irizarry, p. 330). Selecting the public, citizens, and environment as sites for the support of accumulation would not interfere with this rendering invisible of labor. However, to suggest that there is some straightforward "visible" form of labor as the source of surplus value is misguided because of what Zupančič describes as a "paradoxical redoubling" whereby "what makes the products (namely, labor power) also appears with them on the market as one of the products, objects for sale" (Zupančič, p. 33). There is no objective class formation because all classes in capitalism are formed because of this paradox of labor as a non-relation. The rendering invisible of living labor is a condition of it being the source of surplus value. Thus, financialization that renders labor invisible also perpetuates it as a source of value across the many shifting class structures that are possible within capitalism.

This is what makes MMT so valuable to financial capital. Rhetorically, MMT is incomplete, and it is this incompleteness that renders it operant in politics on both the Left and Right. It rhetorically as well as practically "renders invisible" the antagonisms it purports to moderate, assuring both finance capital and exploited workers that they share a single public purpose while enabling a political economy of financial exploitation and expropriation, even potentially imposing new forms of austerity and dispossession under the guise of fiscal stimulus. Consider the case of the JG, which allocates wages for unprofitable work and thus does not disrupt the logic of capital accumulation. Lapavitsas and Aguila note that while the state can create money, "The limits of the state's power are, nonetheless, shown by its inability to determine the measure of value directly in terms of the physical units of labour, that is, in hours of work" (Lapavitsas and Aguila, p. 10). That is, the MMT state is not able to recreate the foundational antagonistic structure of labor as in Zupančič's "redoubled paradox." The state is merely able to approximate value. Thus, the value of JG wages are determined by markets, 
especially financial markets, even though the nominal price is set by the state. Rhetorically, the Left can use MMT to argue for the JG as a source of new income and the Right can look to this movement and see the potential for new forms of expropriation and exploitation within the JG wage. The JG would provide a compromise between the capitalist class and the workers by simultaneously undoing the problem of unemployment for the worker while continuing capitalist accumulation. Such a program, however, would not moderate the structural problems that Marxists associate with unemployment because financialization could turn even full employment into an occasion for exploitation and deprivation. While the JG may provide employment for "all citizens" it would not alter the market logics that create money and direct resources.

Beyond the mere potential for inflation to render the nominal JG wage as a poverty wage, there is the potential for the JG to be financed by labor extracted by the forcing open of markets outside of the credit sovereign nation. Marxists and post-Keynesians have criticized MMT for describing potentials that are only available to developed economies that have credit sovereignty. For example, "The analysis of monetary forms proposed by MMT ignores world money, in sharp contrast to Marxist monetary theory. The global monetary system is hierarchically structured and broad swathes of countries are subordinate" (Lapavitsas and Aguila, p. 30). World money describes the US dollar, which develops its value not only from the US government's decisions on where to allocate money, but also from the productivity of private producers. MMT overemphasizes how credit sovereign governments can direct their monetary policy, however it fails to consider that world markets create incentives for world money. This means that even apparent victories afforded by MMT for the working class within a developed nation come at the expense of workers in other countries because financialization acts globally and transforms national currencies into financial assets in global markets, devaluing other currencies relative to the value 
of world money like the dollar. International financial markets can wrest credit sovereignty away from peripheral countries and so,

MMT's proposal about the impossibility of default of a State when it is indebted in its own currency should take into account that the international demand for assets denominated in peripheral countries is so volatile that in the end the governments in peripheral countries feel strongly constrained by the permanent threat of a capital flight, inevitably incurring in a fiscal policy that is far from autonomous (Verghanini and De Conti, p. 27).

Antagonisms that MMT seeks to moderate domestically can be displaced and then intensified in peripheral countries because of this fear of capital flight. Financialization acts globally, shaping antagonisms between states, while MMT with its rhetorical emphasis on the centrality of the state in economic decisions, fails to consider how hierarchies of money can form internationally. Pyramiding currency is not merely a principle pertaining to the relationship between the state and its domestic financial institutions, it also creates hierarchies of money globally. Indeed, here "pyramiding sovereignty" is at its clearest, as MMT combined with a financialized economy shows the potential of rich states to moderate domestic antagonisms by exporting exploitation and expropriation to the periphery. The rhetoric of MMT can then be levelled against those peripheral countries to declare their fiscal woes as merely the result of poor optimization of money as a rational-technical policymaking tool.

That is all to say antagonisms are preserved precisely by the rhetorical gestures that limit the political economy of MMT to a rational-technical project that moderates antagonisms in the pursuit of accomplishing a public purpose. The political economy of MMT would rely upon its incomplete theory of the economy that is nonetheless able to generate a salient rhetoric because this rhetoric allows antagonisms to go unquestioned. As a theory, MMT does not take sides but instead draws one side into a politics that is merely a rational-technical adaptation to the evolving conditions of financialized capitalism. The rational-technical project of MMT aims to 
alleviate the conditions of exploitation created by capitalist employment and the threat of unemployment through the JG. However, the type of employment the JG creates is unusual in Marxist terms. The JG worker is not an exploited subject because JG labor is generally not productive and thus offers little-to-no surplus to be extracted. Rather, the JG worker performs arbitrary work to appease a "democratic" government that is swayed by private markets that, as Sgambati says, make the state. Bourgeois fears of unemployed workers as drug addicts and criminals fuel demand for the JG as a form of social engineering rather than a form of productive employment. The JG is not an end to the degradation and immiseration of unemployment, but it does manage risks to capital caused by unemployed populations like criminals and addicts (see Chapter II Section II, above). The JG worker is not exploited but is nonetheless subject to capitalist power. This "moderation" of the unemployed subject as a threat to capital is rewarded with the JG wage. Those criminals and addicts who cannot maintain even JG employment are also further immiserated. The JG is a rational-technical project of price discrimination: the workers who are most threatening to capital are immiserated most.

Similarly, even if the JG were to successfully raise the wages of domestic workers, financial domination by wealthy states that can finance JGs has the potential to create new forms of exploitation and expropriation in peripheral countries to underwrite the increases in the JG wage. Indeed, this new form of granting employment is subject to new methods by which wages can be financialized even in developed countries. JG wages would raise aggregate demand in the short run making it possible for the realization of surplus value in this instance, avoiding a crisis through alteration of the money supply. MMT fiscal stimulus could thus avert the crisis of overaccumulation if that stimulus were not recaptured by what Lapavitsas describes as "financial expropriation." Though, Magdoff and Sweezy do hint at "long cycles" that would render even 
these attempts moot, they make no claim to prove those long cycles, only suggesting that figures like Keynes and Kalecki were similarly approaching such conclusions and coming ever closer to the notion that the destruction wrought by these cycles can be avoided only by antagonistic confrontation with the capitalist class (Magdoff and Sweezy p. 47-48). However, it is not as though antagonisms are absent even in the short run, a key discovery of Lapavitsas. Financial expropriation functions via the financialization of ever-increasing segments of the non-financial economy, including housing and wages. The new (short run) forms of income theorized by MMT are ripe for capture by new forms of consumer debt and consumer financial assets. Where Magdoff and Sweezy describe the Great Depression and the 1970s demand shocks as cases of financial crises, Lapavitsas focuses on the development of the financialization of workers' incomes in the period from 2001 to 2007 , culminating in the great financial crash. He writes that "Widespread implication of workers in the mechanisms of finance is the basis of financial expropriation", citing increased amounts of mortgage debt, student debt, insurance, and private retirement investment accounts (Lapavitsas 2009, p. 130). Debts and assets both draw the worker further into dependency upon a hostile financial sector. Similarly, the financialization of nonfinancial institutions has made them less reliant upon borrowing from banks, causing financial institutions to seek new targets for financialization. Financial expropriation functions via the financialization of ever-increasing segments of the non-financial economy, including housing and wages. JG wages would provide new streams of unproductive money to funnel into the financial sector. These wages, largely untethered from commodity production and exchange (to meet the requirements of a JG), would be inflationary, granting increasing amounts of control over political life to financial institutions in their role as purveyors of value. Lapavitsas notes that since the 1970 s the real wages of workers have stagnated as the workers' revenues are 
financialized into a system that "includes increased borrowing (mortgages, general consumption, education, health and so on) but also expanding financial assets (housing, pensions, insurance, money market funds and so on)" (Lapavitsas 2011, p. 620). While MMT proponents advocate for debt cancellation as a stimulus to aggregate demand (see for instance Fullwiller et al. 2018) this can be misleading as under the conditions of a financialized economy as the increases in demand will be returned to the financial sector through other forms of borrowing and expanding assets. Here the rhetorical politics of MMT, based in the moderation of antagonisms, merely creates new forms of exploitation that fall outside the purview of its public purpose. Lapavitsas ties expanding investment in financial assets to decreased labor militancy as worker-investors learn to abhor the financial risks created by their own militancy (Lapavitsas 2011, p. 621). Thus, even attempts to increase real income for workers through policies like a JG are largely captured by financial institutions with the bonus of decreased investment risk created by the pacification of labor. The financial sector's capture of worker incomes is part of a larger problem in the structure of capitalist accumulation itself. This problem is also crucially underwritten by imperial forms of expropriation and exploitation. Lapavitsas writes, "Financialisation has also deepened the complexity of imperialism. Developing countries have been forced to hold vast international reserves that have resulted in net lending by the poor to the rich" (Lapavitsas 2009, p. 115). Thus, workers in the developed countries become increasingly implicated in an imperialist system of finance, further weakening the potential for solidarity between workers of developed nations and peripheral nations. Politically, a working class in a developed country that is captivated by MMT rhetoric will potentially weaken domestic unions and international workers' solidarity to gain the JG wage and further entrenchment within debt and ownership of financialized assets like housing and education. 
Further, paying for unproductive labor via a JG is not capable of addressing the crises of "overaccumulation" that Magdoff and Sweezy suggest have an inherent tie to capitalist speculative investment. They write, "it is true that investment by capitalists is the generator of economic growth. But it is equally true that investment tends to produce an overaccumulation of capital, which in turn leads to recurrent crises" (Magdoff and Sweezy, p. 51). These recurrent crises are driven by a turn to financial speculation that occurs when capital investments begin to produce stagnating returns. The JG, with its unproductive labor does not increase investment because it has little to do with the production of value that can be invested or speculated on. Instead, it is an attempt to create value purely by choosing the point at which money enters the economy.

Financialization is a method of incorporating surplus back into the financial sector and distributing out the risks inherent to the capitalist accumulation process. MMT does not challenge this process so long as it pursues the "public purpose" through "moderation" that treats the dialectical contradiction between classes as a binary opposition instead of taking an antagonistic approach toward the capitalist class. While Foster and McChesney write that financialization "represent[s] the failure of the capital accumulation process at the system's rotting center" it is also true that this failure is in some sense constitutive of today's capitalist accumulation process (Foster and McChesney). To put things in psychoanalytic terms, the rotting center does not imply a previous unrotten capitalism because "the being that is lost is not to be regarded in terms of some originally existing state of plenitude. The subject's desire for a wholeness of being is rather a retroactive effect of the splitting within being, and of the concomitant formation of partial objects of the drive" (Özselçuk and Madra 2014, p. 145). Here, Özselçuk and Madra converge with Zupančič in their discussion of a central paradox as 
foundational. The image of an unrotten center is possible only under the retroactive condition of a rotting center. The rotting center is a necessity for the formation of capitalist political economy. As in Zupančič, where the point is that there is no irreducible, visible, and unfetishized labor, the point here is that the failure of capital accumulation at its rotting center is constitutive of the system's success. Özselçuk and Madra's claim that the capitalist-all is the product of the limit imposed by the success of the capitalist accumulation process is challenged here. They claim that all class conflict in capitalism, "To the extent that it is centered on securing a 'cut' of the surplus value without challenging the 'provided that' status of capitalist appropriation...cannot escape being caught up within the libidinal economy of capitalist-all." (Özselçuk and Madra 2005, p. 88). It is financialization that breaks free of the capitalist-all through the potential of financial capitalism to create successful accumulation through the very failure of accumulation. Financialization and MMT both are responses to money's failure to truly be a "universal equivalent," and the attempt to introduce money as a creature of the state in the MMT neochartalist view of money is thereby fuel for financial speculation on the instances where one dollar of a given commodity fails to be equal to one dollar of the next. The "public purpose" of MMT presents this financialization as a moderate accommodation for workers and financiers instead of a method of articulating the hegemony of the capitalist class across constantly shifting relations of production. Financialization works via the paradoxical (il)logic of labor as both the source of the value of commodities and as commodity itself. Rather than attempt to establish an all-encompassing theory of class relations, financialization is the capitalist non-all because it is necessarily open to the infinite variations of capitalist class structures without regard for a limit. In the following section, this theme is explored in greater depth regarding MMT's rationaltechnical politics and financialization's attempts to transform the fundamental antagonism 
created by the paradox of labor into risk thereby incorporating antagonism as a part of the accumulation process itself.

\section{Financialization and the Incorporation of Antagonism}

The MMT account of financialization is specifically grounded in the notion of a public purpose that moderates between workers and finance as though the two were both otherwise identical forms of liberal subjectivity. This leads to a theory of financialization that can only conceive of financialization in terms of liberal interest-group politics but never in terms of the fundamental antagonisms that define the political. In a description of the global financial crisis of 2007 (GFC), Mitchell et al. write,

Significantly, the sheer volume of financial wealth under management outstripped socially useful investments. To keep returns high, money managers and bankers had to turn to increasingly esoteric financial speculation in areas that not only did not serve the public purpose, but actively subverted it (Mitchell et al., p. 543).

This account veers close to linking financialization to antagonism but stops short. The suggestion that there is a form of speculative finance that does serve the public purpose ignores the structural problems of overaccumulation that Magdoff and Sweezy describe. Following this line of thought there can be no socially useful investment when "the potential savings or surplus generated by the economy normally outweighed the opportunities for profitable investment of that surplus, leading to a tendency to stagnation" (Foster 2010). In other words, the attempt to establish a public purpose that disregards the centrality of antagonism in the formation the social misses the structural tendency of financial speculators to attempt to accumulate endlessly without regard for that public purpose. Financialization, as non-All, subverts the limits of public purpose. It is the reason that every time the public purpose is "established" it must "evolve" before it is ever "accomplished." For MMT, the problem with financialization is that it antagonizes workers, but that it thwarts the politics of compromise central to its conception of public purpose. 
Perhaps the key investment vehicle for illustrating this structural tendency is the derivative. In the MMT account, "Nothing is more symptomatic of the speculative excess than the special collateralised debt obligations (CDOs) created by investment banks to allow hedge funds to bet against homeowners and the holders of securitised mortgages" (Mitchell et al., p. 543). Here again, the problem with derivative swaps is conceptualized in terms of excess - the problem being that CDOs grant financial institutions the ability to behave as though there were an antagonistic relationship with homeowners instead of a harmonious financial sector in which all parties work toward a shared public purpose. Of course, there is such an antagonistic relationship. Jodi Dean gives a Lacanian Marxist reading of the role played by derivatives in the GFC that foregrounds the antagonism inherent in this form of speculation:

At this interface of the extremes of profit and loss, poverty (like risk) isn't an unavoidable byproduct of capitalism but its condition and content - the increase in the number of poor people is an investment opportunity. The system turns in on itself and feeds on its own excesses. The derivative is the commodity form of this reflexive circuit. (Dean 2014, p. $64)$.

This reading suggests that the profitability of the derivative is directly tied to the expropriation of the poor. Dean's contemplation of poverty and risk as condition and content of capitalism contradicts the MMT account in which the harmonious relations of investors and workers is undermined by excessive greed. Indeed, Mitchell et al. suggest a rather unusual policy solution to financial crises: "Top management should have been required to submit resignations as a condition of lending, with the US Federal Reserve or Treasury holding the letters until they could decide which should be accepted" and crimes should be prosecuted (Mitchell et al., p. 547). This attempt to personalize the fault for a crisis created by the structural incentives of financial capital is a limit of a liberal politics that sees deviation from the compromise of a "public purpose" as 
something other than the result of political antagonisms that cannot be contained by rationaltechnical politics.

The inability of rational-technical politics like MMT to apprehend financialization stems from the structure of rational-technical politics and the tension created by the complexity of financial data. Dean dubs popular coverage of the financial sector "finance porn" because of the ways in which this coverage makes financial processes appear incomprehensibly complex to anyone but an ingenious class of "quants" who are "nearly magical geeks, siphoned off from academia" (Dean 2014, p. 67). Though these markets are attributed a kind of rationality through the Efficient Markets Hypothesis (EMH) that asserts "markets must be efficient in the sense that prices reflect all relevant information and quickly adapt to the arrival of any new information through the device of arbitrage" these markets are experienced by most people as a kind of magic rather than rationality (Sotiropoulos and Lapatsioras, p. 92). Dean writes,

Not only are they [derivative markets] too hard for average citizens to understand, but Alan Greenspan couldn't even understand them. In fact, as hundreds of lobbyists for the finance sector worked ceaselessly to teach US members of Congress, derivatives can't be regulated, precisely because no one understands them. Beyond comprehension, they are beyond control. (Dean, 2014, p. 67).

Here, too, there is a process of fetishism that renders labor invisible through endless complexity. Žižek describes the "symbolic Real" as "the signifier reduced to a senseless formula, like the quantum physics formulae which can no longer be translated back into - or related to - the everyday experience of our life world" (Žižek 2001, p. 82). The supposedly endless complexity of derivative markets is an example of the symbolic Real because the endless complexity of financial data effectively serves as a lack of meaning that inaugurates the entire symbolic order of economic meaning. What is allowed and prohibited must be filtered through the demands of the quant. Žižek describes the symbolic Real as the endlessly complex "meaningless 
letter/formula (as in the Real of modern science)" (Žižek 2001, p. 82). It is this meaninglessness that allows the symbolic order to function as a site of political power: one must rely upon the expert knowledge of the scientist, the doctor, or the quant to make sense of one's subjectivity. Further, the Real is tied to the non-relation, which Zupančič describes in terms of sexual nonrelation by writing "non-relation is not simply an absence of relation, but is itself a real, even the Real" (Zupancic, p. 18). That is, the sexual non-relation, or the absence of a universal Idea of sexuality, determines the structure of the partial drives that animate sexuality in its material reality. The non-relation is the Real of sexuality or as Zupančič puts it, "The lack of sexual relation is real in the sense that, as lack or negativity, it is built into what is there, determining its logic and structure in an important way" (Zupancic, p. 18). In class terms, the capitalist classthrough their priestly quants — divines the limits of politics relative to the demands of the esoteric logic of derivative markets. Dean further notes that "Complexity displaces accountability onto knowledge" citing how Goldman Sachs denied having foreknowledge of the GFC as an attempt at self-exculpation (Dean 2014, p. 69). That is, the capitalist class presents itself as merely interpreting signs that appear without an issuer-we weren't wrong, it's just that the heavens would not speak to us!

Here, the temptation to return to MMT is strong. After all, MMT denies all economic augury and asserts the centrality of politics. It places the "accountability" that Dean describes onto the quants and financiers themselves by suggesting resignations and prosecutions as a solution to financial crises. However, MMT does not move away from the rational-mystical model put forward by finance porn. Connors and Mitchell describe how the deification of the economy functions in contrast to their own rational model. They write, "Although subscribers to this view [orthodox macroeconomics] would have us believe this is a rational narrative, in fact it 
represents a type of 'magical thinking' more appropriately associated with medieval views on the relationship between individuals and the world" (Connors and Mitchell, p. 3). They write that the problem with orthodox macroeconomics is that it creates too much distance from the reality of economic relations such that "framing and metaphor triumph over operational reality or theoretical superiority" (Connors and Mitchell, p. 5). The effect of MMT rhetoric is not to reframe a fundamental antagonism between classes, then, but merely to better interpret what the "operational reality" of the economy is. This, however, falls into the same trap as finance porn because it assumes there is some un-fetishized economic relation that can be more closely understood. MMT is invested in an economic "wholeness" that can be brought about by deliberate policy and is thus incompatible with the psychoanalytic view that the "rotting center" of capitalist crisis is the condition of possibility of capitalism itself. Supplanting nature with rational politics makes no difference when politics is itself determined by the flux in the field of the political.

The class antagonism that underwrites capitalism is the result of the "paradoxical redoubling" of labor as commodity and source of the value of commodities. This paradox makes labor under capitalism necessarily fetishized. Merely shifting from the mystifying symbolic Real of the quant to the public purpose politics of MMT misses the paradox at the heart of capitalist relations. MMT sees in the market a kind of magical thinking and thus focuses on the centrality of the state in the economy as if the state were reducible to some rational kernel. The MMT emphasis on "active oversight and control" as a method of ensuring the pursuit of the public purpose relies upon a purely rational subject that can make sense of the paradox of labor.

The orthodox economists are not so wrong, then, when they suggest that the economy functions via tremendous complexity that is more easily likened to a deity or to nature. The 
quants are not too mystical, and the orthodox economists are not too magical. Rather, the problem is that neither they nor the MMT economists have a theory that can conceive of antagonisms founded upon a paradox. The rhetorical gestures by which MMT distinguishes nature from politics are incomplete because they fail to recognize politics as itself a product of a political paradox. Zupančič highlights how humanity (the people, politics) is related to nature itself, writing, "humanity is not an exception to Nature, a deviation from it, but the point of a specific articulation of Nature's own inherent negativity" (Zupančič, p. 15). The point is not that the economy is "like human social collectivity" and "not like nature" but rather that human social life and nature as the Other of human experience are interrelated by way of nature's inherent negativity. The political is precisely the failure of social life to organize itself according to an immutable law, that is, to rationality. In the psychoanalytic view of sex, "to conceive humanity not as an exception to Nature, but as that point of Nature where its lack of 'knowledge' (of sexual law) acquires a singular epistemic form" contrary to the discourse that assumes that there is some rational non-paradoxical reality that can be demystified (Zupančič, p. 15).

The same holds true for derivatives in the Marxist account of fetishism. According to Sotiropoulos and Lapatsioras, debates over the EMH tend to ruminate over the question with the question of whether subjects can grasp the economic realities of capitalism or are "buried in an impenetrable complex economic universe" (Sotiropoulos and Lapatsioras, p. 92). They cite Marx to subvert this debate: "Marx's argument of fetishism breaks with this empiricist problematic. In his train of thought, the observing subject is always already captured within and dominated by the 'supra-sensible' but objective forms of appearance of the existing complex of capitalist power relations" (Sotiropoulos and Lapatsioras, p. 92). That is, the implication of the subject within capitalist power relations is the condition of possibility for any social objectivity. To put it 
in Laclau and Mouffe's terms, social objectivity is the product of hegemonic power.

Financialization organizes social objectivity and the politics of MMT is merely a response to the conditions of that objectivity. Thus, any attempt to (for example) prioritize wellbeing, potential, and sustainability that does not attempt a counter-hegemonic struggle will do so only within the bounds prescribed by the hegemonic capitalist bloc. However, Laclau and Mouffe are also quick to remind us that hegemony is always contingent. They write,

Faced with the rationalism of classical Marxism, which presented history and society as intelligible totalities constituted around conceptually explicable laws, the logic of hegemony presented itself from the outset as a complementary and contingent operation, required for conjunctural imbalances within an evolutionary paradigm whose essential or 'morphological' validity was not for a moment placed in question (Laclau and Mouffe, p. $3)$.

Putting aside Laclau and Mouffe's strict rationalist reading of Marx as a strict rationalist contrary to Sotiropoulos and Lapatsioras, they develop a theory of hegemony as always contingent therefore making every social objectivity contingent. That is, rational observation of the social objectivity can be the means of unmaking that objectivity because it reveals the irrational kernel on which the objectivity is founded. For capitalism, this kernel is the paradox of labor.

However, financialization is not merely one contingent arrangement of social objectivity. While MMT may suggest that there is a unified and rational method for understanding finance, I maintain that financialization is not a creature of politics so much as a creature of the political. The fact that there is "there is no general agreement on what the term [financialization] really explains" suggests it is not some contingent part of a single objective social reality, but rather that it is a characteristic of the political itself (Sotiropoulos and Lapatsioras, p. 89). Likewise, where Fine describes "the contradictory hegemony of the material of finance interests" he actually names financialization's ability to exceed the rationality of neoliberalism (Fine, p. 58).

That is, because hegemony creates social objectivities a "contradictory hegemony" names 
something that is more than hegemony, something that can incorporate the paradox of labor into the accumulation process itself. The requirement for the state to pay massive bailouts to the financial sector after the GFC did not affirm the austerity of neoliberalism, it exceeded it. This excessive dimension of financialization allowed neoliberal capitalism to withstand its own contradiction. It is because this excessive dimension appears in any hegemonic articulation of financialized capitalism that I claim financialization is the capitalist non-all: it is the unintelligible element that makes the hegemony of neoliberalism or MMT intelligible. Put another way, it is the radical open-endedness that paradoxically makes today's capitalism and the potential future capitalism of MMT into closed totalities.

Financialized capitalism does not merely "manage" capitalism by means of repression or the imposition of limits. Rather, its openness becomes a tool for maintaining or exceeding hegemonies as needed. Not content to merely repress labor unrest, the capitalist class uses financial markets to "identify, disperse, and distribute risks" where "the dimension of risk comprises particular fetishist representations of events/outcomes of class struggle" (Sotiropoulos and Lapatsioras, p. 93). That is, financialization is capable of conceptualizing risks to the accumulation process within the accumulation process itself. Derivative prices securitize against risk. The "fetishist representations" of class struggle are responses to the paradox of labor. However, Sotiropoulos and Lapatsioras do not go far enough when they claim that derivatives can make different threats to capital fully fungible. They write, "Derivative markets shape the dimension of abstract risk, imposing commensurability upon different concrete risks and establishing an objective measurement for them" and that the introduction of derivatives in some sense creates a financialization that is "complete" (Sotiropoulos and Lapatsioras, p. 96). This "complete" financialization created by imposed commensurability is not a Lacanian notion. 
Žižek's discussion of the (incomplete) ontology of money from The Sublime Object of Ideology

is illustrative of a more Lacanian notion that I argue can be likewise applied to derivatives:

Things 'materially exist' not when they meet certain notional requirements, but when they fail to meet them - material reality is as such a sign of imperfection. With regard to truth, this means that, for Hegel, the truth of a proposition is inherently notional, determined by the immanent notional content, not a matter of comparison between notion and reality - in Lacanian terms, there is a non-All [pas-tout] of truth (Žižek, 1989, p. xx). The notion of a "complete" financialization ignores this non-All in which the imposed price of class struggle is never precisely equal to the struggle it signifies. That is, the pricing of derivatives cannot prophesy how class antagonisms will arise but can only compensate for the risk of class antagonisms arising. The completeness of financialization is that it is always incomplete, able only to price risk and not adequately price the actual eruptions of antagonistic struggle. The point is not that 'the monetary value of derivatives is an 'objective' measure faced by every market participant in daily market transactions" but that this monetary value always describes class struggles that are beyond the capacity of objective measures to adequately describe because they are based in the paradoxical formulation of the value of labor. Just as money gains its ontological actuality through its failure to perfectly represent some perfectly visible and demystified value of labor (because of the paradoxical redoubling of the value of labor) so too do derivatives gain their ontological actuality through their failure to represent some perfectly intelligible proletarian agent of political struggle. The capitalist process of accumulation incorporates the non-relation of bourgeois and proletarian through the derivative, which allows for the distribution of struggles, but not their end. To "complete" financialization, the derivative introduces the non-All by attempting to represent the infinity of possible capitalist class structures in terms of capitalist accumulation. Money gains its value from its relationship to the commodity, which gains its value from labor that is itself paradoxically a commodity; the derivative gains its value from its relationship to the struggles that result from the multitude of 
attempts to abolish the commodity form, but in financialization that value is expressed in terms of money, which (again) depends upon the commodity form. Thus, the struggle of labor against capital is expressed in the very terms of labor's exploitation. The identification, dispersal, and distribution of risks to capital become productive elements of the capital accumulation process itself.

\section{From MMT to the communist non-All}

The capitalist non-All of financialization is not challenged by MMT because MMT does not comprehend the antagonistic relationship between capital and labor that makes financialization possible. The presence of finance capitalists like Warren Mosler in the intellectual and political development of MMT is not a mistake. Rather, finance capitalists can find in MMT new streams of value to exploit and extract. The development of MMT is the development of one of many possible routes for finance capital to take. However, MMT at several points approaches a Marxist critique of political economy, most notably in its insistence that the economy is the result of human social organization, not a divine or natural social objectivity. However, MMT does not go far enough to assert that human social organization is resistant to rational-technical laws of behavior. That is, MMT does not affirm the political or democracy qua democracy.

Lacanian Marxists conceive of democracy not as a rational-technical tool nor as a set of procedures. Mouffe's agonistic democracy is moderating, though it treats political divisions as the irreducible foundation of social life. By letting go of the MMT view of democracy as an instrument for liberal rational-technical politics and the pursuit of a singular public purpose,

agonistic democracy becomes possible. Žižek points out that the attempts to evade antagonism, corruption, and irrationality in democratic governance are themselves deleterious to democracy. 
He writes, "every attempt to elude this inherent risk and to restore 'real' democracy necessarily brings about its opposite - it ends in the abolition of democracy itself" (Zizek 1989, p. xxviii). The language of risk is important here: financialization does not elude risks, it identifies, disperses, and distributes them. A democratic answer to financialization similarly requires an embrace of risk and antagonism as unavoidable. This is not a cause for despair-one, need not find the ineradicably of antagonism to mean that social life cannot be improved. Indeed, even the idea of "the people" need not be abandoned. In MMT, "We create government as our agent to do things that we cannot easily do ourselves" but this "we" is an attempt to bridge an antagonism instead of accepting the antagonism as such (Connors and Mitchell, p. 4). MMT discussions of "people" oscillate between discussion of liberal subjects seeking economic efficiency and as productive resources to be put to work to achieve that efficiency. In contrast, Dean points to a desire for popular identity that has antagonism embedded within it. She writes, "The objectcause of communist desire is the people and, again, the people not as a name for the social whole but as a name for the exploited, producing majority" (Dean 2012, p. 204). In this vision of communist democracy, antagonism is not to be eradicated but rather is the very basis on which democratic majorities are formed. The condition of unity in this Lacanian Marxist formulation is division itself. Or, as Dean writes, "Communist desire can only be collective, a common relation to a common condition of division" (Dean 2012, p. 191). Here, the Lacanian foundation of desire upon lack allows for the condition of the paradoxical redoubling of the value of labor and the antagonisms it creates to be the basis for the construction of a communist counter-hegemony against capitalism.

Rather than treating the people as a wholly constituted social body, the communist nonAll is the mobilization of "the impossibility of the people", which is premised on the tendency of 
the category of "the people" to exceed "any government, system, organization, or movement," (Dean 2012, p. 204-205). The divisions inherent to social life make any attempt to define or represent the people into a failure. The communist non-All is a politics of the "the people" precisely in that it foregrounds this impossibility, this division in the category of the people itself. In Zupančič's terms, "The proletariat," like the people, "is not the sum of all workers, it is the concept that names the symptomatic point of this system, its disavowed and exploited negativity" (Zupancic, p. 34). What is at issue is not the working class as some positive identity nor popular identity as identity, but the disavowed and exploited negativity that inaugurates capitalist social life. The communist non-All in Özselçuk and Madra proceeds from the belief that there can be no assertion of a positive identity that claims a right to the surplus. They write, "An important condition of possibility of this social reclaiming of surplus is precisely its psychic letting go" (Özselçuk and Madra 2005, p. 93). That is, in the communist non-All the proletariat or the people can reclaim the surplus only by asserting their own negativity and its pivotal role negating the capitalist's claim to have a positive identity as the subject supposed to delegate the distribution of the surplus. Like the capitalist non-All of financialization, the communist non-All is defined by its lack of limits. Financialization, which maintains capitalist relations without respect to any limit, including the limit to maintain the accumulation process itself, resembles the communist non-All because "communist desire subjectifies its own impossibility, its constitutive openness" (Dean 2012, p. 206). This is contrary to MMT, which conceives its own limits as socially objective. The MMT rational-technical project operates only within the prescribed limits provided to it by financialized capital. However, the impossibility of proletarian or popular identity is the foundation of the communist non-All. Similarly, the communist non-All means that communism must make peace with the possibility of "bad communisms" that are 
nonetheless still communist instead of "state capitalist" or some other non-communist form of social organization. Safri and Erçel give the example of a collective of sex workers who pay bribes to the police as an example of a "bad communism" that does away with exploitation in the distribution of surplus and that foregrounds the lack of any particular subject entitled to the distribution of that surplus "while being subject to violence or working grueling hours" (Safri and Erçel, p. 401). The communist non-All means risking these bad communisms. However, these risks are inherent to any form of democratic politics. The attempt to simply do away with antagonisms leads to the destruction of democracy and, eventually, communism itself. By foregrounding antagonism and taking sides rather than attempting to moderate these antagonisms as if they were the conflict of binary opposites, the communist non-All provides a way to ground politics in the political, to give democratic majorities the ability to struggle against their oppressors. Dean writes that, "The people are always non-all, not simply because the many is open and incomplete but because it cannot totalize itself' (Dean 2012, p. 99). There is no social objectivity, no unified public purpose to pursue, but the divisions inherent to the people or the proletariat as categories allow for democratic majorities to form and to do so in opposition to oppressive classes. 


\section{REFERENCES}

Abrahamian, A.A. (2017). The Rock-Star Appeal of Modern Monetary Theory. The Nation. Retrieved March 27, 2021 from https:/www.thenation.com/article/archive/the-rock-starappeal-of-modern-monetary-theory/

Bhattacharya, R., and Seda-Irizarry I.J. (2018). Problematizing the global economy:

financialization and the "feudalization" of capital. In T. Burczak, R. Garnett, \& R. McIntyre (Eds.), Knowledge, Class, and Economics: Marxism without Guarantees (pp. 329-345).

Cohen, P. (2019). Modern Monetary Theory Finds an Embrace in an Unexpected Place: Wall Street. The New York Times. Retrieved March 27, 2021 from https://www.nytimes.com/2019/04/05/business/economy/mmt-wall-street.html

Connors, L., \& Mitchell, W. (2017). Framing modern monetary theory. Journal of Post Keynesian Economics, 40(2), 239-259.

Dean, J. (2012). The Communist Horizon. Verso.

Dean, J. (2014). Still Dancing: Drive as a Category of Political Economy. In H. Feldner, F. Vighi., \& S. Žižek (Eds.), States of Crisis and Post-Capitalist Scenarios (pp. 59-72). Routledge.

Fine, B. (2013). Financialization from a Marxist perspective. International Journal of Political Economy, 42(4), 47-66.

Foster, J. B., \& McChesney, R. W. (2010). Listen Keynesians, It's the System!. Monthly Review, 61(11), 44.

Foster, J. B. (2010). The Financialization of Accumulation. Monthly Review, 62(5), 1.

Fullwiler, S., Kelton, S., Ruetschlin, C., \& Steinbaum M. (2018). The Macroeconomic Effects of Student Debt Cancellation. Levy Economics Institute of Bard College. 
Kelton, S. (2020). The Deficit Myth: Modern Monetary Theory and the Birth of the People's Economy. PublicAffairs.

Laclau, E., \& Mouffe, C. (2001). Hegemony and Socialist Strategy. Verso.

Lapavitsas, C., \& Aguila, N. (2020). Modern Monetary Theory on Money, Sovereignty, and Policy: A Marxist Critique with reference to the Eurozone and Greece. The Japanese Political Economy, 1-27.

Lapavitsas, C. (2009). Financialised capitalism: Crisis and financial expropriation. Historical materialism, 17(2), 114-148.

Lapavitsas, C. (2011). Theorizing financialization. Work, employment and society, 25(4), 611626.

Magdoff, H., \& Sweezy, P. M. (1987). Stagnation and the financial explosion. NYU Press.

Mitchell, W., Wray, L.R., \& Watts, M. (2019) Macroeconomics. Red Globe Press.

Mouffe, C. (2000) The Democratic Paradox. Verso.

Mouffe, C. (2005) On the Political. Routledge.

Nersisyan, Y., \& Wray, L. R. (2010). Does excessive sovereign debt really hurt growth? A critique of This time is different, by Reinhart and Rogoff. Levy Economics Institute of Bard College.

Özselçuk, C., \& Madra, Y.M. (2005). Psychoanalysis and Marxism: From capitalist-all to communist non-all. Psychoanalysis, Culture \& Society, 10(1), 79-97.

Özselçuk, C., \& Madra, Y.M. (2014). Affective Economies: Lacan's Four Discourses against the Historicism of Capitalist Abstraction. In H. Feldner, F. Vighi., \& S. Žižek (Eds.), States of Crisis and Post-Capitalist Scenarios (pp. 141-166). Routledge. 
Palley, T.I. (2013). Money, fiscal policy, and interest rates: A critique of Modern Monetary Theory. Review of Political Economy, 27(1), 1-23.

Palley, T.I. (2019). What's Wrong With Modern Money Theory (MMT): A Critical Primer. Forum for Macroeconomics and Macroeconomic Policies Working Paper, 44, 1-36.

Relman, E. (2019). Alexandria Ocasio-Cortez says the theory that deficit spending is good for the economy should 'absolutely' be part of the conversation. Business Insider. Retrieved March 27, 2021, from https://www.businessinsider.com/alexandria-ocasio-cortez-ommtmodern-monetary-theory-how-pay-for-policies-2019-1

Safri, M., and Erçel, K. (2018). Bad communisms. In T. Burczak, R. Garnett, \& R. McIntyre (Eds.), Knowledge, Class, and Economics: Marxism without Guarantees (pp. 393-404).

Sgambati, S. (2015). The Significance of Money Beyond Ingham's Sociology of Money. European Journal of Sociology, 56(2), 307-339.

Sotiropoulos, D.P. and Lapatsioras, S. (2014). Financialization and Marx: Some Reflections on Bryan's, Martin's and Rafferty's Argumentation. Review of Radical Political Economics, 46(1), 87-101.

Vergnhanini, R., \& De Conti, B. (2017). Modern Monetary Theory: A Criticism From the Periphery. Brazilian Keynesian Review, 3(2), 16-31.

Žižek, S. (1989). The Sublime Object of Ideology. Verso.

Žižek, S. (2001). On Belief. Routledge.

Žižek, S. (2004). The Structure of Domination Today: A Lacanian View. Studies in East European Thought, 56(4), 383-403.

Zupančič, A. (2017). What is Sex?. MIT Press. 